\title{
El uso del Derecho EXTRANJERO Y DEL DERECHO INTERNACIONAL POR PARTE DEL Tribunal Constitucional CHILENO DURANTE EL PERIODO 2006-2007*
}

["The use of Foreign law and International law by the Chilean Constitutional Court During 2006-2007”]

\author{
Humberto Nogueira Alcalá ${ }^{* *}$ \\ Universidad de Talca, Chile
}

\begin{abstract}
RESUMEN
Sobre la base de doble perspectiva, de Derecho comparado en orden al empleo de elementos extra sistémicos o no nacionales por los jueces constitucionales en su argumentación, y de la doctrina constitucional que considera sistemas constitucionales abiertos y no centrados en sí mismos y cerrados, analizaremos si el Tribunal Constitucional chileno utiliza el Derecho constitucional y la jurisprudencia constitucional de otros países latinoamericanos y europeos, como asimismo, el Derecho
\end{abstract}

\begin{abstract}
On a double perspective on the use of Comparative law by constitutional judges in order to use extra-systemic or foreign elements in their argumentation, and on the constitutional doctrine that contemplates open constitutional systems and not selfcentered ones, we will analyze whether the Chilean Constitutional Court uses the Constitutional Law and the Constitutional Jurisprudence of other LatinAmerican and European countries, as well as the International Conventional Law
\end{abstract}

* Este artículo forma parte del proyecto Enlace FondeCyt de la Universidad de Talca VAC No 600 520, resolución 584/2010, desarrollado por el autor, titulado: "Análisis de la jurisprudencia del Tribunal Constitucional sobre uso del Derecho no doméstico por parte del Tribunal Constitucional chileno (periodo 2006-2007)”.

** Doctor en Derecho por Universidad Católica de Lovaina la Nueva; profesor titular de Derecho Constitucional y Director del Centro de Estudios Constitucionales de la Facultad de Ciencias Jurídicas y Sociales de la Universidad de Talca; vicepresidente del Instituto Iberoamericano de Derecho procesal Constitucional; presidente de la Asociación Chilena de Derecho Constitucional; miembro Asociado Academia Internacional de Derecho Comparado. Dirección postal: 2 Norte 685, Talca, Chile. Correo electrónico:nogueira@utalca.cl 
convencional internacional de los derechos humanos y las resoluciones de sus órganos de aplicación. Asimismo analizaremos los motivos por los cuales el Tribunal Constitucional hace uso del Derecho y la jurisprudencia extranjera e internacional durante el periodo 2006-2007.

Palabras clave

Jurisdicción constitucional - Uso del Derecho no doméstico por el Tribunal Constitucional chileno - Diálogo entre jurisdicciones. on Human Rights and the resolutions of their enforcement bodies. Likewise, we will analyze why during 2006-2007 the Constitutional Court used the Foreign and International Law.

KEYWORDS

Constitutional Jurisdiction - Use of foreign Law by the Chilean Constitutional Court - Dialogue between jurisdictions.

[RECiBIDo el 29 de junio y ACEPTADo el 25 de julio de 2011].

\section{INTRODUCCIÓN}

La razón del comienzo cronológico de la investigación jurisprudencial del Tribunal Constitucional chileno en marzo de 2006, se fundamenta en que, en dicha fecha, entra a operar parcialmente la nueva integración de dicho Tribunal determinada por la reforma constitucional de 2005, aunque sus plenos efectos se produzcan posteriormente, ya que a dicha fecha solo hay una integración parcial de nuevos magistrados elegidos con los nuevos criterios determinados por la reforma, integrándose los Ministros elegidos por el Congreso Nacional, y renovándose algunos de aquellos nombrados por el Presidente de la República y la Corte Suprema de Justicia. A ello debe agregarse que sólo a partir de 2006 el Tribunal Constitucional ejercerá sus nuevas competencias en materia control reparador de constitucionalidad concreto a través de las acciones de inaplicabilidad y de control reparador abstracto a través de las acciones de inconstitucionalidad.

La expresión "diálogo de los jueces" es utilizada de manera habitual en el Derecho comparado para describir el fenómeno a través del cual algunas jurisdicciones consideran, en diversas modalidades los precedentes de jurisdicciones no nacionales provenientes de un Estado Extranjero o de una jurisdicción internacional o supranacional, sobre lo cual hay una abundante literatura ${ }^{1}$, diálogo que produce o puede producir una fertilización cruza-

${ }^{1}$ Ponthoreau, Marie Claire, Le recours a l'argument de droit comparé par le juge constitutionnelle. Quelques problèmes théoriques et tecniques, en MéLIN-SoucramaNIEN, Ferdinand (editor), L'interpretation constitutionnelle (Paris, Dalloz, 2005), pp. 145 ss.; Canivet, G. The Practice of Comparative Law by the Supreme Courts: Brief Re- 
$\mathrm{da}^{2}$ de los criterios con los cuales los jueces resuelven los casos concretos dentro de su competencia.

En materia de diálogos jurisdiccionales puede distinguirse los diálogos horizontales que son aquellos que se desarrollan entre tribunales de un mismo nivel, donde el diálogo es libre y espontáneo, de uso voluntario, ya que no deriva de ninguna obligación internacional ni constitucional. Esta circulación jurisprudencial de carácter horizontal que utiliza el Derecho constitucional extranjero y la jurisprudencia de otras jurisdicciones constitucionales nacionales es un fenómeno jurídico que se ha desarrollado en las últimas décadas, a lo cual han contribuido las nuevas tecnologías informáticas, las cuales permiten conocer con facilidad las sentencias de las jurisdicciones extranjeras a través de las respectivas páginas web con las sentencias a texto completo, como asimismo, las reuniones formales de intercambio de reflexiones entre los órganos jurisdiccionales de carácter constitucional tanto en el contexto latinoamericano, como iberoamericano y la Comisión de Venecia.

Por otra parte, es necesario señalar que un segundo tipo de diálogo es de carácter vertical, este implica la consideración de tratados de derechos humanos y las sentencias de las jurisdicciones transnacionales ${ }^{3}$ o internacionales de derechos humanos que son vinculantes para los Estados Partes y las cuales impactan en las jurisdicciones nacionales, como es el caso de la jurisprudencia de la Corte Interamericana de Derechos Humanos, en el ámbito regional americano. Este diálogo es producto de la obligación del Estado de respetar estándares normativos y jurisprudenciales determinados por el Derecho internacional vinculante y de sus órganos de interpretación

flextions on the Dialogue Between the Judges in French and European Experience, en Tulane Law Review, 80 (2006), pp. 1377-1400; Maus, Didier, Le recours aux précédents étrangers et le dialogue des cours constitutionnelles, en Revue Francaise de Droit Constitutionnel, 80 (2009), pp. 675-696; SPERTI, Angioletta. Le difficoltà connesse al ricorso alla comparazione a fini interpretativi nella giurisprudenza costituzionale nel contesto dell'attuale dibattito sull'interpretazione, en Diritto Pubblico Comparato ed Europeo, 2 (2008), pp 1033 ss.; Lollini, Andrea, Confronting Comparative Methods: Approaches to Using Extra-Systemic Parameters by the Canadian Supreme Court and the South African Constitutional Court, en Muller, A. S. - Loth, M.A., Highest Courts and Internationalisation of Law (The Hague, Hague Academic Press, 2009), pp. 165-182; BURgorgue-LARSEN, Laurence, La formación de un Derecho constitucional europeo a través del diálogo judicial, en Asociación de Constitucionalistas españoles (editores), El Derecho constitucional europeo (Valencia, Tirant Lo Blanch, 2010); De VergotTINI, Giuseppe, Oltre il dialogo tra le corti (Bologna, Il Mulino, 2010); JACKson, Vicky, Constitutional Engagement in a Transnational Era (Oxford - New York, Oxford University Press, 2010).

${ }^{2}$ Slaughter, Anne-Marie, A Global Community of Courts, en Harvard International Law Journal, 44 (2003), pp. 192-204.

${ }^{3}$ Maus, Didier, Le recours aux précédents étrangers, cit. (n. 1), p. 682. 
y aplicación. Como señala De Vergottini, los tribunales o cortes nacionales deben garantizar en sus resoluciones una "compatibilidad constructiva" y una armonía con las disposiciones vinculantes de la Convención y de sus órganos jurisdiccionales de aplicación que condicionan y cuasi predeterminan la decisión del juez nacional ${ }^{4}$.

Respecto de la circulación de jurisprudencia extranjera en las resoluciones de las jurisdicciones constitucionales de América Latina, ella se hace presente en diversos Tribunales y Cortes Constitucionales, entre los que destaca la Corte Constitucional de Colombia y de Perú, como asimismo, las Cortes Supremas de Argentina y la Sala Constitucional de la Corte Suprema de Costa Rica, para solo señalar algunos casos a manera ejemplar.

Más común en las sentencias de las jurisdicciones constitucionales latinoamericanas es la cita de las convenciones internacionales en materia de Derechos Humanos, como asimismo, la jurisprudencia de la Corte Interamericana de Derechos Humanos, como ocurre entre otros tribunales constitucionales con los de Colombia ${ }^{5}$ Perú, como asimismo por las cortes supremas de Argentina ${ }^{6}$ y México $^{7}$, en los últimos años.

El objeto del presente artículo es el de analizar cómo impacta en el Tribunal Constitucional chileno este escenario de creciente convergencia y de interpenetración de los ordenamientos jurídicos, de cooperación y diálogo internacional entre magistraturas constitucionales, cuya realidad es innegable en los inicios de este tercer milenio, como asimismo, cómo se inserta el Tribunal Constitucional chileno en el movimiento que se ha denominado de justicia transnacional, lo que lleva a una práctica judicial que utiliza crecientemente el método de Derecho comparado.

A partir del trabajo de Bruce Ackerman, The Rise of Word Constitu-

${ }^{4}$ De Vergottini, Giuseppe, Oltre il dialogo tra le corti, cit. (n. 1), p. 53.

${ }^{5}$ Escobar-Martínez, Lina Marcela, El uso del precedente extranjero por parte de la Corte Constitucional colombiana, en Revista Colombiana de Derecho Internacional, 13 (Bogotá, noviembre de 2008), pp. 391-409.

${ }^{6}$ BAzÁn, Víctor, El Derecho internacional de los derechos humanos desde la óptica de la Corte Suprema de Justicia de Argentina, en Revista de Estudios Constitucionales, 8 (Santiago, Centro de Estudios Constitucionales de Chile, Universidad de Talca, Ed. Abeledo Perrot - Legal Publishing, 2010) 2., pp. 359-388; Carnota, Walter, Paper Uso del Derecho extranjero por Corte Suprema Argentina, en VIII Congreso Mundial de la Asociación Internacional de Derecho Constitucional, México, diciembre de 2010, "workshop" No 12: Enriquecimiento de la jurisprudencia a través del Derecho comparado (México D. F., 2010).

${ }^{7}$ Castilla, Karlos, El Derecho de origen internacional en la interpretación constitucional de la Suprema Corte de Justicia de la Nación, en Revista Cuestiones Constitucionales, 23 (Ciudad de México, julio diciembre de 2010), pp. 219-243. 
cionalism $^{8}$, se hace presente en la doctrina constitucional la función que desempeñan los jueces constitucionales como protagonistas de la circulación jurídica, mediante la utilización de argumentos "extra sistémicos" en las sentencias, como son las alusiones al Derecho extranjero, al Derecho internacional y a las sentencias de los respectivos tribunales constitucionales o a las jurisdicciones internacionales, especialmente aquellas con competencia sobre derechos humanos.

A su vez, Peter Häberle, ha destacado e impulsado la consideración del Derecho comparado como quinto método de interpretación del Derecho".

En Chile, la apertura constitucional al Derecho Internacional de los Derechos Humanos, está presente con el artículo 5 inciso $2^{\circ}$ de la Constitución y los derechos esenciales asegurados por los tratados de derechos humanos ratificados y vigentes, como asimismo con el reconocimiento de la jurisdicción obligatoria y vinculante de la Corte Interamericana de Derechos Humanos.

En el ámbito del uso del Derecho convencional internacional la reforma de 2005, ha aportado en el artículo $54 \mathrm{~N}^{\circ} 1$ inciso $6^{\circ}$ de la Carta Fundamental una regla que armoniza con los artículos 31 y 27 de la Convención sobre Derecho de los tratados de Viena de 1969, al determinar que "las disposiciones de un tratado sólo podrán ser derogadas, modificadas o suspendidas en la forma prevista en los propios tratados o de acuerdo a las normas generales de Derecho internacional".

En este artículo se constata un cambio significativo de perspectivas en el Tribunal Constitucional chileno entre 2006 y 2007, respecto del recurso a las fuentes del Derecho no nacional, tanto del Derecho constitucional extranjero y la jurisprudencia constitucional extranjera, como asimismo del Derecho internacional, especialmente del Derecho internacional de los derechos humanos y de la jurisprudencia de sus órganos de aplicación, para lo cual seguiremos de cerca la sistematización metodológica de Drobnig y Van $\operatorname{Erp}^{10}$ y de Queralt Jiménez ${ }^{11}$.

${ }^{8}$ Ackerman, Bruce, The Rise of Word Constitucionalism, en Virginia Law Review, 83 (1997), p. 771.

${ }^{9}$ HäBerle, Peter, Métodos y principios de la interpretación constitucional, en FERRER MAC-GREgor, Eduardo (coordinador), Interpretación constitucional (Ciudad de México, D.F., Porrua, 2005), I.

${ }^{10}$ Drobnig , Ulrich - VAN ERP, Sjef (editores), The Use of Comparative Law by Court. Academia Internacional de Derecho Comparado (La Haya, Kluwer Law International, 1998).

${ }^{11}$ Queralt Jiménez, Argelia, Los usos del canon europeo en la jurisprudencia del Tribunal Constitucional: Una muestra del proceso de armonización europea en materia de derechos fundamentales, en Revista Teoria y Realidad Constitucional, 20 (2007), pp. 435-470. 


\section{ANÁlisis de la JURISPRUdENCIA DEL \\ Tribunal Constitucional del año 2006}

\section{Los fallos.}

El año 2006 es el primer año de operación del Tribunal Constitucional con una integración que responde, a lo menos en parte, a la reforma constitucional de 2005, como asimismo, el Tribunal comienza a hacer uso de sus nuevas competencias en materia de control reparador de constitucionalidad de preceptos legales en control concreto (artículo 93 № 6 ) y abstracto (artículo 93 No 7), dictando sentencias en dichos ámbitos.

En el año 2006, es posible verificar que las sentencias del Tribunal Constitucional no contienen citas de otros ordenamientos constitucionales ni de tratados de derechos humanos, como asimismo no hay expresión institucional de referencias a jurisprudencia de otros tribunales constitucionales o de cortes internacionales de derechos humanos. Hay un solo caso de una sentencia que cita Derecho constitucional extranjero y jurisprudencia de jurisdicciones constitucionales extranjeros, en la que no hubo decisión por empate de votos (rol No 555). Sin embargo, es posible constatar que diversos ministros del Tribunal, en sus votos particulares concurrentes o disidentes utilizan el Derecho extranjero o no doméstico para reforzar su argumentación jurídica en diversas materias, como asimismo, en algunos casos para demostrar la inadecuación de utilización de doctrinas que responden a contextos jurídicos distintos.

Las citas están referidas a sentencias del Tribunal Constitucional español (roles $\mathrm{N}^{\circ}$ 479, 480 y 546) en materia de predeterminación legal de conductas y sanciones en Derecho sancionador penal y administrativo. Mientras en otro voto concurrente de la sentencia rol No 480 y 546 se determina que los valores de la democracia constitucional no exigen asimilar el principio de la legalidad del Derecho penal al administrativo sancionador, si bien los ordenamientos alemán y español acogen la aplicación del principio del Derecho sancionador penal en su aplicación al Derecho sancionador administrativo, otros ordenamientos como los de Francia e Italia no lo hacen.

Asimismo, el Ministro Jorge Correa en rol No 480 plantea que la asimilación de la norma respectiva de la Constitución española no puede traspasarse al Derecho constitucional chileno ya que el primero sujeta toda sanción y no solo las penas como lo hace el chileno al principio de legalidad.

En sentencia rol No 546, referente a la institución del "solve et repete", en la que no hay decisión por empate de votos, el grupo de ministros que no considera inaplicable por inconstitucional en el caso concreto en análisis el "solve et repete", hacen alusión a sentencias del Tribunal Constitucional de España que no consideran inconstitucional la aplicación de dicha institución 
en algunos casos específicos en materia laboral, como asimismo, a legislación de Argentina y Estados Unidos que contienen la institución en materia tributaria, bajo la fórmula "pague primero, litigue después"; también citan sentencia del tribunal constitucional de Italia y de la Corte Suprema de Colombia que sí lo consideran inconstitucional. Dichos Ministros llegan a la conclusión de que el "solve et repete" no es constitucional en sí mismo, debiendo ser analizado en sus efectos en cada caso, no siéndolo en el caso analizado. Los otros cinco ministros del Tribunal consideran que el solve et repete es inconstitucional solo sobre argumentaciones de Derecho constitucional chileno.

En sentencia rol $N^{\circ} 555$, el requirente demanda la inaplicabilidad por inconstitucionalidad del artículo 116 del Código Tributario que posibilita la delegación de jurisdicción de los directores regionales de Impuestos Internos en funcionarios subordinados para actuar como tribunal tributario, lo que considera contrario al debido proceso constitucional y al artículo 8 de la Convención americana de derechos humanos.

El Tribunal Constitucional resuelve el requerimiento determinando la inaplicabilidad por inconstitucionalidad de la delegación de jurisdicción de los Directores Regionales de Impuestos Internos en funcionarios inferiores, en un fallo que más tarde permitirá de oficio al mismo Tribunal Constitucional determinar la expulsión de dicha norma legal del ordenamiento jurídico, como asimismo, llevará al gobierno a desarrollar Tribunales Tributarios especializados. La sentencia no analiza ni argumenta en torno al artículo $8^{\circ}$ de la Convención americana de derechos humanos, ni utiliza jurisprudencia de la Corte Interamericana de Derechos Humanos.

\section{Conclusiones sobre los fallos.}

Puede señalarse que el Tribunal Constitucional en 2006, en sentencias de inaplicabilidad no aplica consideraciones de Derecho internacional de derechos humanos contenidas en tratados internacionales sobre la materia en su argumentación jurídica específica. El Tribunal Constitucional tampoco utiliza en el periodo jurisprudencia de sus órganos de aplicación de la Convención americana sobre derechos bumanos ni de los tratados de Naciones Unidas.

Las menciones que se encontraron en unos pocos fallos al Derecho no doméstico se refieren sólo a citas o reflexiones alusivas al Derecho constitucional extranjero y a la jurisprudencia extranjera, realizadas en forma espontánea y voluntaria, pero ellas se encuentran solamente en votos concurrentes (roles No 479, 480 y 546).

En algunos casos, pese a la invocación de atributos de derechos esenciales contenidos en tratados internacionales por los requirentes, el Tribunal no se 
pronuncia respecto de ellos en su ratio decidendi, lo que puede considerarse un déficit de argumentación respecto del requerimiento (sentencia rol No 555).

\section{AnÁlisis de SENTENCIAS del TRIBUnal Constitucional del año 2007}

\section{Los fallos.}

En el año 2007, el Tribunal Constitucional comenzará a realizar una más frecuente utilización del Derecho no doméstico, tanto en la perspectiva del Derecho constitucional y la jurisprudencia constitucional extranjera, tanto europea, como del ámbito americano, como asimismo, utilizará el Derecho internacional de los derechos humanos y la jurisprudencia de la Corte Interamericana de Derechos Humanos, aun cuando esta última sólo en votos disidentes.

Entrando a un análisis cuantitativo más fino, puede señalarse que durante el año 2007 el Tribunal Constitucional, en sus sentencias en que entra a resolver el fondo de los requerimientos presentados en acciones de inaplicabilidad por inconstitucionalidad, en tres sentencias utilizan normas de Derecho constitucional extranjero de Estados Unidos, Alemania, España, Francia e Italia (roles $\mathrm{N}^{\circ} 718,759$ y 773 ). Una sentencia se refiere a concepciones sobre justicia administrativa en el Derecho positivo de diversos estados en referencia abstracta y sin precisión (rol № 616). Respecto de las citas de jurisprudencia de otros tribunales constitucionales, puede establecerse: doce sentencias citan jurisprudencia del Tribunal Constitucional español ( roles № 519, 527, 549, 576, 616, 664, 718, 759, 773, 783, 786, 790); en tres sentencian cita jurisprudencia de la Corte Constitucional alemana (roles $\mathrm{N}^{\circ} 616$, 786, 790); en tres sentencias cita jurisprudencia del Consejo Constitucional francés (roles № 616, 664 y 786); en dos sentencias cita jurisprudencia del Tribunal Constitucional de Italia (roles 616 y 786); en dos sentencias cita jurisprudencia del Tribunal Constitucional de Perú (roles № 718 y 786); en dos cita jurisprudencia de la Corte Suprema de México (roles No 718 y 780); y en dos sentencias cita jurisprudencia de la Corte Constitucional de Colombia (roles No 790 y 804).

Asimismo, en una sentencia se hace referencia genérica al Derecho de Francia, Inglaterra, Alemania, España, Estados Unidos y al Derecho hispanoamericano con referencias a diversos países considerando la diversidad de sistemas de justicia administrativa (rol No 616).

A su vez, respecto de uso del Derecho Internacional de los Derechos $\mathrm{Hu}-$ manos ratificado por Chile y vigente, el Tribunal Constitucional lo empieza a utilizar como reforzamiento de sus propias argumentaciones y como parte 
del parámetro de control de constitucionalidad por la norma de reenvío del artículo 5 inciso $2^{\circ}$ de la Constitución.

En cinco sentencias utiliza los derechos asegurados por el Pacto Internacional de Derechos Civiles y Políticos de Naciones Unidas (roles No 519 , $576,739,783$ y 807); en cuatro sentencias utiliza los derechos y garantías asegurados por la Convención americana de derechos humanos (roles No 519 , 576,739 y 807). En dos sentencias realiza referencias a derechos asegurados por la Declaración americana de derechos humanos (roles No 519 y 576); en una sentencia se utilizan los principios y derechos asegurados por la Convención sobre derechos del niño ( $r o l N^{\circ} 786$ ). En una sentencia se utilizan los derechos asegurados por la Convención sobre no discriminación de la mujer (rol No 698). En una sentencia se utiliza las reglas de la Convención sobre Derecho de los tratados de Viena (rol No 804).

EL Tribunal Constitucional durante el año 2007, utiliza también el "soft law" (Derecho blando) en materia de derechos humanos, en tres sentencias utiliza la Declaración sobre protección de la persona contra la tortura u otros tratos crueles, inbumanos o degradantes de la Asamblea de Naciones Unidas de 9 de diciembre de 1975 (roles No 519, 576 y 786). En una sentencia cita las Reglas minimas para la administración de justicia de Menores de las $\mathrm{Na}$ ciones Unidas ("Reglas de Beijing") en rol No 786 . Una sentencia alude a las Reglas minimas sobre medidas no privativas de libertad ("Reglas de Tokio"), en rol No 807.

Finalmente, en una sentencia se cita el Código Modelo Tributario para América Latina (rol № 718).

2. Análisis cualitativo de las sentencias respecto del uso del Derecho internacional de los derechos humanos.

Puede sostenerse, desde el punto de vista cualitativo, que el Tribunal Constitucional, en 2007, por primera vez, empleará derechos esenciales contenidos en tratados internacionales de derechos humanos como parámetro de control de constitucionalidad de disposiciones legales internas en control reparador concreto de constitucionalidad mediante acciones de inaplicabilidad por inconstitucionalidad en materia de prisión por deudas (roles No 576 y 807); la Convención sobre no discriminación de la mujer (rol № 698); en materia de presunción de inocencia (rol No 739).

a) El uso del canon interamericano en sentencias roles $\mathrm{N}^{\circ}$ 576 y N$^{\circ} 807$.

i) Prisión por delito de apropiación indebida de dineros de trabajadores por empleador y no existencia de prisión por deudas. En efecto, en el rol 576, el Tribunal Constitucional acertadamente considera que no se está en presencia de una prisión por deudas, sino que ante una apropiación indebida 
del empleador de dineros que son propiedad de los trabajadores, por lo cual no hay una vulneración de la Convención americana de derechos humanos, aunque al realizar tal reconocimiento el tribunal razona integrando el Derecho a no ser objeto de prisión por deudas como parte del parámetro de control de constitucionalidad en forma tácita, como lo precisa en su considerando vigésimo tercero. Su argumentación se realiza tanto en torno a la Convención americana de derechos humanos, como al Pacto internacional de derechos civiles y politicos de Naciones Unidas.

El Tribunal Constitucional abunda en razonamientos del porqué la norma legal chilena no vulnera las obligaciones en materia de respeto y promoción de derechos humanos contenidos en la Convención americana de derechos humanos y al Pacto internacional de derechos civiles y politicos, a la cual reenvía el artículo 5 inciso $2^{\circ}$ de la Constitución, como reflexiona el tribunal en su considerando vigésimo quinto y sexto: “Que por lo demás y a mayor abundamiento, contrariamente a lo sostenido por la requirente, el precepto legal en cuestión se encuentra en armonía con los deberes impuestos al Estado en materia de derechos esenciales que emanan de la naturaleza humana, tal como lo ordena el artículo $5^{\circ}$ inciso segundo de la Constitución Política de la República, particularmente respecto de diversos tratados internacionales que probiben la denominada 'prisión por deudas'. En efecto, el artículo 11 del Pacto internacional de derechos civiles y políticos establece que 'nadie será encarcelado por el sólo hecho de no poder cumplir una obligación contractual', esto es, una deuda emanada de un contrato civil. Sobre el punto, la doctrina ha señalado que esto significa que la privación de libertad basada en el incumplimiento de obligaciones legales, sean de Derecho privado o público, es aceptable. De modo que cuando un tribunal impone la privación de libertad para compeler al cumplimiento de una obligación legal ello no importa una vulneración de la prohibición de la prisión por deudas (Manfred Nowak, U.N. Covenant on Civil and Political Rights. CCPR Commentary. N.P. Engel, Publisher. Kerl, Strasbourg, Arlington). De este modo, se ha concluido que las obligaciones contractuales a que suelen aludir los pactos internacionales dicen más bien relación con obligaciones civiles emanadas tipicamente del Derecho privado y no de aquellas establecidas por la ley (Sarah Joseph, Jenny Schultz \& Melissa Castan, The International Covenant on Civil and Political Rights. Cases, Materials and Commentary, Second Edition)".

En el mismo sentido, el Tribunal Constitucional español ha sentenciado que "sólo puede hablarse con propiedad de prisión por deudas cuando la insolvencia tiene su base en el incumplimiento de una obligación contractual" (230/1991); "Que en armonía con lo anterior, la Declaración americana de derechos humanos, antecedente directo del Pacto de San José de Costa Rica, en su artículo 25, inciso segundo, probibe ser detenido 'por incumplimiento 
de obligaciones de carácter netamente civil'. Precisamente por lo mismo, el Convenio europeo para la protección de los derechos humanos y las libertades fundamentales admite la posibilidad de la detención o privación de libertad por desobediencia a una orden judicial o para asegurar el cumplimiento de una obligación establecida en la ley"”.

Así el Tribunal Constitucional no solo utiliza como parte del parámetro de control de constitucionalidad los derechos asegurados por el Pacto internacional de derechos civiles y politicos de Naciones Unidas y la Convención americana sobre derechos humanos, sino que considerará las interpretaciones de ellas efectuadas por comentarios académicos sobre la materia, además de citar también jurisprudencia del Tribunal Constitucional español, todo lo cual le permite delimitar, es decir determinar el contenido, el haz de atributos y garantías, como sus fronteras o límites, acerca del Derecho a no ser objeto de prisión por deudas.

Luego de desentrañar los contenidos de dicho Derecho en el ámbito de los tratados internacionales de derechos humanos vinculantes para el Estado Chileno, el Tribunal Constitucional determina que existe una armonía entre dichas obligaciones de respeto y promoción de los derechos esenciales contenidos en ellos y el mandato constitucional del artículo $19 \mathrm{~N}^{\circ} 7$ de la Carta Fundamental, como lo explicita en su considerando vigésimo séptimo: "Que, como resulta claro, los más importantes tratados internacionales de derechos humanos, en concordancia con el mandato constitucional establecido en el articulo $19 N^{\circ} 7$ de la Constitución, tuvieron especial preocupación por la libertad de las personas frente a los abusos en que pudiere incurrir el Estado mediante detenciones ilegales o arbitrarias, esto es, que no obedecieran al quebrantamiento de un mandato legal o a una causa debidamente justificada en la razón y la equidad. En esta misma línea, proscribieron la privación de la libertad por deudas, entendiendo por tal aquellas que tuvieran como antecedente el mero interés pecuniario de un individuo ('una obligación contractual' u'obligaciones de carácter netamente civil'), de modo de no poner al servicio de causas únicamente particulares o privadas el aparato represivo del Estado. De este modo se ha aceptado la privación de libertad frente al grave incumplimiento de determinados deberes legales en la medida que estuviere envuelto el interés social y el buen funcionamiento de la comunidad, en otras palabras, el bien común, que constituye el fin que debe perseguir el Estado, tal como lo reconoce el artículo $1^{\circ}$ de nuestra Carta Fundamental".

El Tribunal Constitucional concluirá su razonamiento sobre la materia haciendo una analogía respecto del contenido del artículo $7 \mathrm{~N}^{\circ} 7$ de la Convención americana, que autoriza a los tribunales a determinar la privación de libertad de personas por incumplimiento de deberes alimentarios a la privación de libertad por incumplimiento de deberes en materia de enterar 
cotizaciones pertenecientes a los trabajadores por parte de su empleadores a las instituciones previsionales, lo que realiza en los considerandos vigésimo octavo y vigésimo noveno: "Que, adicionalmente, en concordancia con lo ya razonado, el numeral $7^{\circ}$ del artículo 7 de la Convención americana de derechos humanos reitera que 'nadie será detenido por deudas. Este principio no limita los mandatos de autoridad judicial competente, dictadospor incumplimientos de deberes alimentarios'. La discusión en torno al establecimiento de la disposición, en particular las observaciones de los paises miembros, permite sostener que su finalidad se vincula con la proscripción de la privación de libertad derivada de deudas propiamente civiles $y$, en modo alguno, al incumplimiento de las obligaciones legales que involucran intereses de toda la sociedad".

ii) En el rol No 807, el Tribunal Constitucional determina que en la Ley $N^{\circ} 18.216$, el legislador no ha dispuesto que se encarcele a una persona por no pagar una deuda, sino que ha establecido una condición para que a la persona condenada por un delito pueda concedérsele o mantener el goce del beneficio de cierta libertad.

El requirente, don Cristián Arias, en representación de don Libertino Rivas Poblete, ha formulado una acción de inaplicabilidad por inconstitucionalidad, planteando que los artículos impugnados [ 17 letra d) y 19 de la Ley $\left.\mathrm{N}^{\circ} 18.216\right]$ resultan contrarios a la prohibición de prisión por deudas, consagrada en el artículo 7.7 de la Convención americana sobre derechos bumanos y el artículo $11 \mathrm{del}$ Pacto internacional de derechos civiles y politicos y al principio de igualdad ante la ley contemplado en el artículo $19 \mathrm{~N}^{\circ} 2$ de la Constitución.

El requirente alega que el resultado contrario a la Carta Fundamental se produciría por vulnerarse la prohibición de prisión por deudas, que se encuentra establecida en el artículo 7.7 de la Convención americana de derechos humanos o "Pacto de San José de Costa Rica" y en el artículo 11 del Pacto internacional de derechos civiles y políticos, mandatos que, según alega, se refieren a todo tipo de deudas y no sólo a las de carácter contractual, y que, además, deben ser aplicados en Chile como si fuesen de rango constitucional, en virtud de lo dispuesto en el inciso segundo del artículo $5^{\circ}$ de la Constitución Politica.

El Tribunal Constitucional en su considerando décimo razona en el sentido de que "para acoger la acción interpuesta resultaría necesario que se verificara una doble condición: en primer lugar, que existiera contradicción entre el articulo 19 de la Ley $N^{\circ} 18.216$-o más precisamente entre los efectos que produciría la aplicación de ese precepto en la gestión pendiente- y alguna de las normas de Derecho internacional invocadas, y que, además, y en segundo lugar, en virtud de lo establecido en el artículo 5, inciso segundo, de la Carta 
Fundamental, tal contradicción habilitara a esta Magistratura para declarar inaplicable el precepto legal".

El Tribunal parte por analizar el texto de los derechos asegurados convencionalmente en el Pacto internacional de derechos civiles y politicos y la Convención americana sobre derechos humanos en el considerando undécimo y décimo tercero: "Que el artículo 7.7 del Pacto de San José de Costa Rica prescribe: 'Nadie será detenido por deudas. Este principio no limita los mandatos de autoridad judicial competente dictados por incumplimientos de deberes alimentarios'. Por su parte, el artículo 11 del Pacto Internacional de Derechos Civiles y Politicos dispone: 'Nadie será encarcelado por el solo hecho de no poder cumplir una obligación contractual. Que, como puede apreciarse, las normas de Derecho internacional que se invocan como infringidas no son idénticas y la primera es más comprensiva que la segunda, en cuanto esta última sólo probibe el encarcelamiento por obligaciones contraidas en virtud de un contrato, como expresa inequivocamente su texto. Esta sola restricción es suficiente para desestimar la contradicción alegada a su respecto, pues la deuda que se presenta como causal de indebido encarcelamiento no proviene de un contrato, sino de una sentencia judicial. En consecuencia, y en lo que sigue, se continuará el análisis de la eventual contradicción con la norma contenida en el Pacto de San José de Costa Rica, ya transcrita. De la sola lectura del texto de la norma del Pacto de San José transcrita fluye inequivoco su sentido: probibir que una persona pueda sufrir privación de libertad como consecuencia del no pago de una deuda. Lo prohibido es que la conducta de no pagar una obligación pecuniaria sea tratada jurídicamente como causa de una sanción privativa de libertad. Por su parte, en la gestión pendiente y por aplicación de lo dispuesto en el artículo 19 de la Ley $N^{\circ} 18.216$, el requirente no está en riesgo de sufrir privación de libertad en razón de no pagar una deuda, sino que la causa de su eventual pérdida de libertad es la comisión de un delito, el de manejo en estado de ebriedad causando la muerte de Maria Isabel Vázquez Muga, hecho establecido por la sentencia judicial ejecutoriada dictada por el Sexto Tribunal Oral en lo Penal de Santiago con fecha 6 de diciembre de 2006. El pago de la indemnización constituye, en la especie, una condición para mantener vigente el goce de un beneficio -el de la libertad vigilada-en el modo de cumplir la sentencia impuesta. A través de lo prescrito en la Ley $N^{\circ} 18.216$, el legislador no ha dispuesto que se encarcele a una persona por no pagar una deuda, que es la conducta probibida por la norma del Derecho internacional invocada, sino que ha establecido una condición para que a la persona condenada por un delito pueda concedérsele o mantener el goce del beneficio de cierta libertad. No se infringe la norma internacional si una de las condiciones para conceder y luego para mantener el beneficio carcelario es el pago de la indemnización civil 
derivada de los daños del delito, pues el incumplimiento de ese pago no es causa de la privación de libertad, sino el delito que lo antecede".

Realizado dicho razonamiento sobre el artículo 7.7 del "Pacto de San José de Costa Rica”, y los atributos del derecho a la libertad personal garantizados en él, los que utiliza de acuerdo, además, al principio de progresividad y favor persona, ya que usa la disposición de la Convención americana sobre derechos humanos que ofrece mayor protección en la materia que el artículo del Pacto internacional de derechos civiles y politicos de Naciones Unidas, considerándolo como parte del parámetro de control de constitucionalidad, el Tribunal Constitucional en el considerando décimo cuarto, considera: "Que constituiría un error lógico confundir la causa de la pérdida de la libertad -en la especie el delito-con la condición para mantener un beneficio en el modo de cumplir la sentencia condenatoria que afecta al responsable de tal delito. Una es la causa por la cual se priva de libertad (responsabilidad en el delito judicialmente establecido) y otra es una condición sin la cual no puede mantenerse un beneficio carcelario. Confundir ambas es incurrir en un error lógico que llevaría a darle un sentido y alcance al derecho a no sufrir encarcelamiento por deudas que resulta incompatible con el objeto y fin de la norma contenida en el Pacto Internacional. Expandir caprichosamente el alcance de la probibición de la actividad punitiva estatal terminaria además por hacer perder eficacia a la norma de Derecho internacional, cuyo alcance acotado constituye parte de la fuente de su legitimidady de la fuerza de su invocación. Además, expandirla así $y$ de modo contradictorio con sus términos haria más improbable la concesión de beneficios carcelarios condicionados".

El Tribunal Constitucional en su considerando décimo sexto, reflexiona también sobre la consistencia de las normas nacionales sobre libertad vigilada con el soft law internacional, constituido en este caso por las "Reglas mínimas sobre las medidas no privativas de libertad", conocidas como las "Reglas de Tokio": "Que, por su parte, el sentido que se ha dado al precepto legal contenido en los artículos 17, letra d) y 19 de la Ley No 18.216 , consistente en que el pago de la indemnización es una condición del beneficio de la libertad vigilada y no la causa de la privación de libertad, no sólo fluye del sentido de los términos contenidos en esos preceptos ya transcritos, sino además y sobre todo de la naturaleza de la institución de la libertad vigilada, que es un beneficio alternativo a la cárcel, destinado a favorecer la reinserción y rehabilitación de las personas que han delinquido, sujeta a ciertas condiciones, cuya no verificación inicial o cuyo incumplimiento posterior no causa la cárcel, ya que ella es efecto del delito, sino que impide o revoca el beneficio. Por lo demás, y a mayor abundamiento, en la tradición del "probation" y de los esfuerzos internacionales que nuestro país recogió al adoptar el sistema de libertad vigilada, no sólo se considera legítimo, sino que se recomienda tener 
presente los intereses de la víctima a la hora de conceder este tipo de beneficios. Al respecto, en el $8^{\circ}$ Congreso de las Naciones Unidas sobre Prevención y Tratamiento del Delincuente, realizado en Cuba entre el 27 de agosto y el 7 de septiembre de 1990, se aprobaron una serie de proyectos dentro de los cuales se contemplaron las Reglas minimas sobre las medidas no privativas de libertad, conocidas como las "Reglas de Tokio", en cuyo numeral 8.1. se recomienda: "La autoridad judicial, que tendrá a su disposición una serie de sanciones no privativas de la libertad, al adoptar su decisión deberá tener en consideración las necesidades de rehabilitación del delincuente, la protección de la sociedad y los intereses de la víctima, quien será consultada cuando corresponda". Por su parte, en el punto 12.2 de dichas reglas se establece: "Las obligaciones que ha de cumplir el delincuente serán prácticas, precisas y tan pocas como sea posible, y tendrán por objeto reducir las posibilidades de reincidencia en el comportamiento delictivo e incrementar las posibilidades."

iii) En el rol No 698, el Tribunal determinará que una norma laboral que establece que una trabajadora contratada a plazo fijo y que se pide autorización judicial como determina la ley para extinguir la obligación contractual laboral no genera discriminación considerada por artículo 11 de la Convención aludida.

Doña Ivonne Osses Gálvez ha formulado una acción de inaplicabilidad por inconstitucionalidad respecto del artículo 174 del Código del Trabajo, en la causa rol No 2660-06, caratulada "Sociedad Concesionaria Autopista Central con Osses Gálvez”, sobre desafuero maternal. La requirente, señala que al quedar embarazada, la relación contractual válidamente celebrada se ha subsumido en una situación de mayor importancia en el ordenamiento jurídico, como es el embarazo y la protección de la maternidad, para lo cual el Código del Trabajo establece como garantía el fuero, que debe superponerse a cualquier estipulación contractual.

El abogado de la requirente también determina como infringido el artículo $11 \mathrm{~N}^{\circ} 2$ de la convención que elimina toda clase de discriminación contra la mujer, disposición que tendría carácter de garantía constitucional por aplicación del artículo 5 , inciso $2^{\circ}$ de la Constitución Política, que impone a los órganos del Estado el deber de respetar y promover los derechos esenciales que emanan de la naturaleza humana y que estén garantizados en tratados internacionales ratificados por Chile y que se encuentren vigentes.

El Tribunal Constitucional razona entendiendo incorporado al parámetro de control al Derecho y garantía contenido en el artículo 11 de la Convención sobre no discriminación de la mujer ("Convención Belém Do Pará"), sintetizando su ratio decidendi en el considerando noveno de la sentencia: "Que, no obstante lo que arguye la requirente, no se deduce de las normas constitucionales que cita como base de su acción de inaplicabilidad la 
obligación de otorgar a la mujer trabajadora que sea parte de un contrato de trabajo a plazo fijo, por razón de su embarazo y maternidad, una protección tal que impida a su empleador, en términos absolutos, poner término al contrato de trabajo que celebró con ella por un tiempo determinado. En efecto: Tal es lo que ocurre con el fuero maternal, establecido en el artículo 201 del Código del Trabajo y que corresponde aplicar al juez laboral competente de acuerdo con el artículo 174 del mismo Código, no discrecionalmente sino de acuerdo con el mérito del proceso y según el cual el juez podrá conceder la autorización para poner término al contrato de trabajo, entre otras causales, conforme a la que contempla el artículo $159 \mathrm{~N}^{\circ} 4$, esto es, 'vencimiento del plazo convenido en el contrato'. La naturaleza temporal del vinculo laboral es un factor objetivo y relevante que no puede reprocharse al legislador por haberlo tenido en cuenta como un factor que autorice a poner término al contrato de trabajo en el caso de los trabajadores que gocen de fuero./No se divisa, asimismo, una discriminación contra la mujer y una vulneración a la estabilidad de la misma en el empleo, garantias a las que se refiere el artículo $11 N^{\circ} 2$ de la Convención Internacional invocada también por la requirente en relación con el artículo $5^{\circ}$, inciso segundo, de la Constitución Política, pues la aplicación del fuero maternal que se cuestiona favorece precisamente a la mujer frente al trabajador varón y se trata, en el caso sub lite, de un empleo de carácter temporal que, en lugar de terminar al vencimiento del plazo convenido, que es lo que ocurre por regla general en este tipo de contrato de trabajo, requiere de autorización judicial para que se extinga la relación laboral".

b) Sentencias que incorporan derechos y garantías aseguradas por el artículo $8^{\circ}$ de la Convención americana sobre derechos humanos y $14 \mathrm{del}$ Pacto internacional de derechos civiles y politicos de Naciones Unidas.

i) El Tribunal Constitucional en sentencia rol 739 de 21 de agosto de 2007 , incluye a la presunción de inocencia como principio contenido en el debido proceso, a partir de la Convención american a sobre derechos humanos y del Pacto internacional de derechos civiles y politicos de Naciones Unidas.

Mario Ruiz Zurita, en representación de Hartmut Wilhem Hopp Miottel, ha formulado una acción de inaplicabilidad por inconstitucionalidad respecto de los artículos 1 inciso $2^{\circ}$ y 292 del Código Penal, en relación a la causa rol No 2182-98 (ex Colonia Dignidad). Señala que las normas constitucionales vulneradas son los artículos 5 inciso segundo; $19 \mathrm{~N}^{\circ} 7$, letra e), y $\mathrm{N}^{\circ} 26$. El requirente denuncia la vulneración del principio de inocencia, al que adjudica el carácter de presunción.

Como determina el Tribunal Constitucional, la Constitución Política no consagra explícitamente el derecho a la presunción de inocencia, "pero parte de la doctrina lo deduce indirectamente de la probibición de presumir 
de Derecho la responsabilidad penal, en armonía con el Derecho a la libertad individual y la seguridad de que los preceptos que regulen o limiten las garantias constitucionales no pueden a fectar la esencia de las mismas".

A su vez, el Tribunal Constitucional considera los tratados internacionales sobre derechos humanos ratificados por Chile, en los que sí aparece reconocido formalmente. La Convención american a sobre derechos humanos ("Pacto de San José de Costa Rica"), en el artículo 8.2, dispone que "toda persona inculpada de delito tiene Derecho a que se presuma su inocencia mientras no se establezca legalmente su culpabilidad" y que "durante el proceso todapersona tiene Derecho, en plena igualdad, a las garantias minimas" que enuncia. A su vez, el Pacto internacional de derechos civiles y politicos, en el artículo 14.2, reitera que "toda persona acusada de un delito tiene Derecho a que se presuma su inocencia mientras no se pruebe su culpabilidad conforme a la ley".

El Tribunal Constitucional utiliza los atributos de tal derecho contenidos en ambos tratados como parte del contenido del derecho que servirá de parámetro de control de constitucionalidad, como se deduce de sus considerandos octavos a decimoprimero: "Octavo. Que dicho principio, que más bien se podria referir al 'trato de inocente', importa la obligación de considerar al imputado como si fuera inocente, reduciendo las limitaciones y perturbaciones en sus derechos al minimo indispensable para el cumplimiento de los fines del proceso. Por ello, las restricciones -como las medidas cautelares- tienen carácter excepcional y provisional y deben responder a la necesidad de su justificación./ La llamada 'presunción de inocencia', como lo señala el requerimiento, está compuesta de dos reglas complementarias./ Una primera regla de trato o conducta hacia el imputado, segun la cual toda persona debe ser tratada como inocente mientras una sentencia de término no declare lo contrario (nulla poena sine iudicio)./ Una segunda regla de juicio, en cuya virtud el imputado no debe probar su inocencia, correspondiendo a la parte acusadora acreditar, suficientemente, la existencia del hecho punible y la participación del acusado (in dubio pro reo)./ La denominada 'presunción de inocencia' no pertenece a la categoría de las presunciones legales o judiciales; obsta para ello la inexistencia de un nexo lógico entre el hecho base y el hecho presumido. Como señala un autor, "es un estado jurídico de una persona involucrada en un proceso penal y debe recogerse como principio orientador en la actividad de investigación y decisión. La inocencia no necesita cumplir con los elementos de la presunción, ya que se trata de la situación jurídica de una persona, que requiere ser desvirtuada por quien la sindica como culpable" (Juan Colombo C., El Inocente delincuente, publicado en Revista "Informativo Jurídico", Editorial Jurídica de Chile, № 37, septiembre de 2006, página 5)./ Noveno: Que el requerimiento atribuye al inciso segundo del artículo $1^{\circ}$ del Código Penal contener un presunción de dolo, la que sería contraria al principio constitucional de inocencia./ La doctrina penal, en esta 
materia, no es uniforme. Hay autores que identifican la voluntariedad con el conocimiento de la ilicitud de la conducta - la conciencia de la antijuridicidad-, conceptuándola como elemento de la culpabilidad.Para otros, la voluntariedad se refiere al elemento subjetivo, que comprende tanto el dolo como la culpa. Los últimos la entienden como alusión a la voluntariedad del acto y no del resultado./ Con todo, incluso los que le atribuyen contener una presunción de dolo, estiman que 'no se trata de una presunción arbitraria e injusta: es simplemente aceptar que lo ordinario es que las personas actúen con libertad y a conciencia de los actos que ejecutan y de su licitud o ilicitud. Es la regla general, no la excepción'(Alfredo Etcheberry, Derecho Penal Tercera Edición, tomo 1, páginas 310 y 311)./ Por lo demás, en cuanto se trata de una presunción simplemente legal, puede ser desvirtuada./ Décimo. Que la presunción de voluntariedad, cualquiera sea el alcance que se le otorgue, no se opone al principio o estado de inocencia, por cuanto su aplicación no representa una inversión de la carga de la prueba -en términos de que incumba al imputado acreditar su inocencia-, atendida la aplicación imperativa en el procedimiento penal, tanto en las fases de instrucción como de acusación, de preceptos que imponen el deber al juez de establecer la participación culpable del inculpado./ En efecto, el artículo 109 del Código de Procedimiento Penal - cuerpo legal que contiene las normas de enjuiciamiento a que se sujeta este proceso - declara que' el juez debe investigar, con igual celo, no sólo los hechos y circunstancias que establecen y agravan la responsabilidad de los inculpados, sino también los que les eximan de ella o la extingan o atenúen'./ A su vez, el articulo 456 del mismo texto prescribe que 'nadie puede ser condenado por delito sino cuando el tribunal que lo juzgue haya adquirido, por los medios de prueb a legal, la convicción de que realmente se ha cometido un becho punible y que en él ha correspondido al procesado una participación culpable y penada por la ley'./ Decimo Primero. Que, en consecuencia, en este caso no se produce una aplicación contraria a la Constitución del artículo $1^{\circ}$, inciso segundo, del Código Penal”.

ii) En sentencia rol $N^{\circ} 783$ de treinta y uno de agosto de 2007, el Tribunal Constitucional integra los atributos y garantías del derecho al debido proceso de la Convención americana sobre derechos humanos, en su artículo $8^{\circ}$, como asimismo el principio de tipicidad del artículo $9^{\circ}$ de la misma Convención.

La requirente, doña María Reyes Kokisch, ha formulado una acción de inaplicabilidad por inconstitucionalidad respecto de las siguientes disposiciones del Código Orgánico de Tribunales, las cuales son el inciso $3^{\circ} \mathrm{del}$ artículo 551 en la parte que establece que el tribunal superior resolverá la apelación en cuenta; el inciso $2^{\circ}$ del artículo 539, en la parte que la Corte de Apelaciones podrá imponer medidas correccionales; el artículo 541 inciso $2^{\circ}, 539$ inciso $2^{\circ}, 536,542,544 \mathrm{~N}^{\circ}, 557$ y 558 . Alega que estos preceptos inciden en el expediente antecedentes de pleno rol No 1920-2006 ad. 
El Tribunal considera, en este caso, como normas que forman parte del parámetro de control de constitucionalidad: "1.-[...] Como normas constitucionales infringidas se invocan ocho preceptos contenidos en la Carta Fundamentaly, en virtud de lo dispuesto en su artículo $5^{\circ}$, se funda también la pretensión de inaplicabilidad en la contrariedad que las normas legales tendrian con cinco preceptos de la Convención Americana de Derechos Humanos, en adelante Pacto de San José de Costa Rica. A fin de considerar y concluir acerca de cada una de las cuestiones planteadas de un modo sistemático, los razonamientos que siguen se agruparán en tres capitulos, cada uno de los cuales considerará tópicos de impugnación según el principio o valor constitucional que se alega infringido: El primero agrupará las alegaciones de contrariedad entre el debido proceso y ciertas disposiciones legales (II); el segundo, la falta de tipicidad legal suficiente de las faltas (III) y, por último, la vulneración del principio de igual protección de la ley en el ejercicio de los derechos (IV).

Agregó el Tribunal Constitucional en el punto 3 que: "3. [...] En resumen, alega que resolver de plano en primera instancia y en cuenta en segunda contraria las garantias de un debido proceso en cuanto a: a) la racionalidady justicia que exigen el inciso quinto del número $3^{\circ}$ del artículo 19 de la Carta Fundamental y preceptos del Pacto de San José de Costa Rica; b) en cuanto al Derecho a ser oído que garantiza el Pacto de San José de Costa Rica en el numeral $5^{\circ}$ de su artículo $8^{\circ}$; c) en cuanto al Derecho a defensa que garantiza el inciso segundo del numeral $3^{\circ}$ del artículo 19 de la Constitución, y d) en cuanto a la publicidad que garantiza el inciso segundo del artículo $8^{\circ}$ de la Carta Fundamental."

El Tribunal Constitucional centra en esencia su razonamiento en el considerando décimo primero y décimo segundo en el cual considera que la norma jurídica cuestionada vulnera efectivamente las reglas del debido proceso, en virtud de las cuales determinará la inaplicabilidad de algunas de las disposiciones legales cuestionadas para el caso concreto considerado: "Que, en consecuencia, aun cuando se trate de un 'resolver de plano' con las caracteristicas antes indicadas, esta Magistratura concluye que resultaria contrario a un procedimiento racional y justo que la Corte de Apelaciones proceda de este modo, sin relación pública ni escuch ar ella misma a la parte afectada al decidir los cargos que se formulan en contra de la requirente, pues lo que debe decidir en la gestión pendiente es una cuestión trascendente, no sólo para derechos esenciales de la requirente, sino también y especialmente delicada para la independencia de la que debe gozar un secretario cuando, obrando como juez subrogante, dicta una sentencia definitiva. En la gestión pendiente, la Corte de Apelaciones habrá de resolver acerca de la conducta ministerial de una Secretaria de un Juzgado de Letraspor diversas actuaciones, algunas de las cuales las ha efectuado como juez subrogante, y entre las medidas que vienen recomendadas aplicarle se encuen- 
tra su suspensión, traslado y apertura de un cuaderno de remoción. Un justo y racional proceso exige que cuestiones de esa trascendencia para los derechos de la requirente, pero, sobre todo, para el buen servicio judicial y la independencia de sus magistrados, no sean resueltas de plano, sino en audiencia a la que tenga Derecho a asistir la afectada. No se escapa a esta Magistratura que esta declaración obligará a la Corte de Santiago a resolver esta materia previa vista de la causa, lo que demandará de ella un tiempo mayor que si lo conociera de plano, lo que naturalmente la distraerá de otras materias que también requieren de su tiempo para resolverse oportunamente. Con todo y por la trascendencia y delicadeza del tema, la racionalidad y justicia de los procesos, garantidos por la Carta Fundamental, exigen que asi se haga".

Luego el Tribunal Constitucional razona en términos de si existe respecto de las disposiciones cuestionadas una afectación del principio de tipicidad, realizando el Tribunal Constitucional un análisis del artículo 9 de la Convención americana sobre derechos humanos, en su considerando vigésimo sexto: "Que lo razonado hasta aqui acerca del modo en que está consagrado el principio de tipicidad no se ve alterado por lo dispuesto en el articulo $9^{\circ}$ de la Convención americana de derechos humanos o Pacto de San José de Costa Rica, aunque se considerara, como pide la requirente, como parámetro de rango constitucional. El precepto invocado de ese Pacto establece 'Artículo 9. Principio de Legalidady de Retroactividad. Nadie puede ser condenado por acciones u omisiones que en el momento de cometerse no fueran delictivos según el Derecho aplicable. Tampoco se puede imponer pena más grave que la aplicable en el momento de la comisión del delito. Si con posterioridad a la comisión del delito la ley dispone la imposición de una pena más leve, el delincuente se beneficiará de ello'. Como puede apreciarse del solo lenguaje de esa norma internacional, ella, al igual que la Carta Fundamental chilena, establece el principio de legalidad -y su componente de tipicidad-en materias penales. Asi, se refiere a delitos, penas, condenados y delincuentes. Ello hace innecesario referirse a la jerarquia de la norma de un tratado que no se contrapone con lo establecido en la Constitución".

En voto disidente, tres ministros opinan en su considerando vigésimo tercero que: "[...] este Tribunal Constitucional ha entendido, razonamiento que los disidentes hacen suyo, que los principios de legalidad y tipicidad que inspiran el orden penal y que se encuentran recogidos en los tres últimos incisos del $N^{\circ} 3$ del articulo 19 de la Constitución Política se aplican también a todas las manifestaciones del Derecho sancionador del Estado, incluyéndose el disciplinario de los funcionarios judiciales. Asi por lo demás se desprende de la historia fidedigna del establecimiento de esta norma, habida consideración que, como lo señaló el Presidente de la Comisión de Estudio de la Nueva Constitución: 'en principio, hay opinión coincidente de todos los miembros de la Comisión, en el 
sentido de considerar la situación de todas las leyes sancionatorias y no sólo las de orden criminal" (sesión No 113, 10 de abril de 1975, p. 10)'”.

Además hacen uso de una sentencia del Tribunal Constitucional español para reforzar su opinión, en el considerando vigésimo cuarto: "Que estos principios imponen, en palabras del Tribunal Constitucional español, "la exigencia material absoluta de predeterminación normativa de las conductasy de las sanciones correspondientes, exigencias que [...] afectan a la tipificación de las infracciones, a la graduación y escala de las sanciones y a la correlación entre unas y otras, de tal modo que [...] el conjunto de las normas aplicables permita predecir, con suficiente grado de certeza, el tipo y el grado de sanción susceptible de ser impuesta' (T. Constitucional de España, sentencia de 29 de marzo de 1990, citada en García de Enterría, Eduardo, y Fernández, Tomás-Ramón, Derecho Administrativo, p. 177)".

En esta sentencia sorprende nuevamente que habiendo considerado el Tribunal Constitucional los atributos y garantías de los derechos considerados en los artículos 8 y 9 de la Convención americana sobre derechos humanos, el Tribunal Constitucional no haya considerado la jurisprudencia de la Corte Interamericana respecto del Derecho a la jurisdicción, el Derecho de defensa y el Derecho a la publicidad del procedimiento, sobre lo cual hay una abundante y rica línea jurisprudencial asentada de la Corte Interamericana de Derechos Humanos ${ }^{12}$.

c) En control preventivo de proyectos de ley en trámite parlamentario, en el rol No 786, utiliza el interés superior del menor en aplicación de la Convención sobre derechos del niño para enjuiciar el proyecto de ley de responsabilidad penal juvenil.

Con fecha 19 de mayo de 2007, treinta y tres señores diputados, que representan más de la cuarta parte de los miembros en ejercicio de esa Corporación, dedujeron un requerimiento en conformidad al artículo $93 \mathrm{~N}^{\circ} 3^{\circ}$ de la Constitución, con el objeto de que se declare la inconstitucionalidad del artículo único, número tres, del proyecto de ley modificatorio de la Ley No 20.084, que establece un sistema de responsabilidad de los adolescentes por infracciones a la ley penal, en la parte en que dicha norma modifica el artículo $23 \mathrm{~N}^{\circ} 1$ del citado cuerpo legal.

El requerimiento plantea que una indicación concretada durante la tramitación del proyecto de ley sería inconstitucional por contradecir el artículo $5^{\circ}$, inciso segundo, de la Constitución Política, con relación al artículo 37 letra

${ }^{12} \mathrm{Al}$ respecto véase: Nogueira Alcalá, Humberto, El debido proceso en la Constitución y el sistema interamericano (Santiago, Librotecnia, 2007). 
b), de la Convención sobre los derechos del niño y al principio de no retroceso en materia de derechos humanos.

Los requirentes aducen que la referida indicación parlamentaria además de vulnerar la Convención sobre derechos del niño, vulnera la prohibición de retroceso en el respeto de los derechos humanos que se encuentra consagrada en los Pactos internacionales de derechos civiles y politicos y de derechos económicos, sociales y culturales.

En este caso el canon convencional se incorpora o integra al canon del derecho fundamental del niño asumiendo atributos o elementos del derecho no asegurados por el texto constitucional, compatibilizando el canon constitucional con el convencional, lo que lleva a reconocer la delimitación y configuración del derecho con ese nuevo contenido que está contenido en la Convención, que es el interés superior del menor, el que se utiliza como parámetro de control de constitucionalidad, razonando sobre el mismo, para sostener que este no se afecta por la disposición cuestionada del proyecto de ley en tramitación parlamentaria.

El Tribunal Constitucional realiza el análisis de constitucionalidad integrando los atributos de la Convención sobre derechos del niño, como es el interés superior del menor en el parámetro de control de constitucionalidad. Sin embargo en Tribunal incurrirá en déficit de razonamiento respecto de lo pedido por el requerimiento, ya que no se pronuncia ni considera el principio de no retroceso en materia de derechos humanos, postulado de interpretación básico en materia de derechos humanos, además de norma convencional en diversos tratados ratificados por Chile y vigentes como señala el requerimiento.

$\mathrm{Al}$ respecto el Tribunal Constitucional determina: "Vigésimo sexto: Que la referida inconstitucionalidad consistiria, especificamente, a juicio de los requirentes, en que al establecer la norma impugnada del proyecto modificatorio de la Ley $N^{\circ} 20.084$, como unica sanción posible, para el tramo depenalidad superior a 5 años, la de internación en régimen cerrado, configuraría una violación al articulo $5^{\circ}$, inciso segundo, de la Carta Fundamental que consagra el deber de los órganos del Estado -como es el caso del legislador-de respetar y promover los derechos esenciales del ser humano garantizados por la Constitución y los tratados internacionales ratificados por Chile y que se encuentren vigentes. Ello, porque el legislador no habría respetado el principio del interés superior del niño, consagrado en el artículo 3.1 de la Convención sobre los Derechos del Niño, asi como los artículos 37, 40 y 41 de la misma, según los cuales la privación de libertad de los adolescentes debe ser la ultima ratio e imponerse por el menor tiempo posible. Vigésimo séptimo: Que planteada, en esos términos, la cuestión de constitucionalidad sometida a la decisión de este Tribunal, ella debe ser necesariamente desechada, por las razones que se expresarán./ Cabe 
destacar, en tal sentido, que todo el sistema de responsabilidad penal del adolescente, en nuestro pais, está basado en la necesidad del respeto a sus derechosy, en particular, del "interés superior" del mismo. Ello se comprueba al examinar en detalle la normativa contenida en la Ley $N^{\circ} 20.084$ [...]. Vigésimo octavo: Que, en ese contexto, no se divisa cómo una indicación parlamentaria destinada a eliminar la opción del juez de aplicar la internación en régimen semicerrado para aquellos adolescentes condenados por delitos que merezcan penas superiores a 5 años de privación de libertad, al menos durante los dos primeros años de la condena, pueda implicar una vulneración al inciso segundo del artículo $5^{\circ}$ de la Carta Fundamental"

En el considerando vigésimo octavo comentado y en el considerando vigésimo noveno, el Tribunal Constitucional recurre a la jurisprudencia constitucional de tribunales constitucionales de Sudamérica y de Europa, para determinar que es un principio de Derecho constitucional usual en el Derecho constitucional que el tipo y cuantía de las sanciones es una materia de reserva de ley.

En voto concurrente, el ministro Jorge Correa Sutil, abunda aún más en argumentar sobre la no vulneración del proyecto de ley sobre los atributos de los derechos del niño, contenido en la Convención sobre derechos del niño, como asimismo en diversas normas de "soft law", entre ellas las Reglas minimas para la administración de la justicia de menores de las Naciones Unidas, conocidas como "Reglas de Beijing".

d) El Tribunal Constitucional en tres de sus sentencias especifica criterios básicos para que los derechos contenidos en tratados internacionales puedan utilizarse como parámetro de control de constitucionalidad (rol No 698, rol No 804 y rol $\mathrm{N}^{\circ} 807$ ).

i) En sentencia rol $N^{\circ} 804$, de veintiocho de diciembre de 2007, el Tribunal Constitucional Tribunal precisa que no debe confundirse el respeto de los derechos esenciales que emanan de la naturaleza humana, con las normas de interpretación y aplicación de tratados

El Tribunal Constitucional frente a la posición del requirente planteará un punto sustantivo en materia de aseguramiento de derechos contenidos en tratados internacionales en consideración del artículo 5 de la Constitución. El Tribunal precisa que lo protegido por este artículo son los derechos esenciales de la persona asegurados por los tratados internacionales y no las normas sobre interpretación y aplicación de tratados: "Décimo sexto: Que, respecto de la eventual infracción del artículo quinto, inciso segundo, de la Constitución, es menester indicar que su fundamento confunde las normas sobre interpretación y aplicación de los tratados con el respeto de los derechos esenciales que emanan de la naturaleza humana, sin precisar la cuestión de constitucionalidad que 
se plantea a esta Magistratura. Aún más, no se identifica o caracteriza diferenciadamente el derecho esencial garantizado por un tratado internacional ratificado por Chile que se veria vulnerado. La impugnación no aparece, pues, fundada razonablemente, por lo que este Tribunal la desechará".

ii) El Tribunal Constitucional, en su sentencia rol No 807 sostendrá un enfoque metodológico, en su considerando $10^{\circ}$ que, para acoger una acción interpuesta en que se invocan derechos fundamentales contenidos en tratados internacionales como parte del parámetro de control de constitucionalidad.

El Tribunal Constitucional en el considerando $10^{\circ}$ de esta sentencia establece que deben cumplirse dos condiciones para que se pueda determinar la inaplicabilidad por inconstitucionalidad en virtud de derechos asegurados por tratados internacionales: $i$ ) que exista una contradicción entre el contenido del precepto legal interno, o en su caso los efectos que su aplicación generarían en el caso concreto, con el derecho fundamental o esencial contenido de alguna de las normas de Derecho internacional invocadas; y ii) que en virtud de lo establecido en el art 5 de la Constitución, en su inciso $2^{\circ}$, tal contradicción habilite al Tribunal constitucional a declarar inaplicable el precepto legal "para acoger la acción interpuesta resultaria necesario que se verificara una doble condición: en primer lugar, que existiera contradicción entre el articulo 19 de la Ley $N^{\circ} 18.216$-o más precisamente entre los efectos que produciria la aplicación de ese precepto en la gestión pendiente- y alguna de las normas de Derecho internacional invocadas, y que, además, y en segundo lugar, en virtud de lo establecido en el articulo $5^{\circ}$, inciso segundo, de la Carta Fundamental, tal contradicción habilitara a esta Magistratura para declarar inaplicable el precepto legal" (considerando $10^{\circ}$ )

iii) El Tribunal Constitucional en su fallo rol No 804, sobre la labor de interpretación de las normas de tratados y de Derecho interno, el Tribunal Constitucional acude a los artículos 31 y 27 de la Convención sobre Derecho de los tratados de Viena de 1969, como asimismo establece la obligación del juez de realizar los máximos esfuerzos para cumplir de buena fe las disposiciones y fines del tratado.

En efecto, el Tribunal Constitucional precisará, en su sentencia rol $\mathrm{N}^{\circ}$ 804, considerando $4^{\circ}$, que: "En este sentido, la regla de oro en la interpretación internacional está dada por el artículo $31 N^{\circ} 1$ de la Convención de Viena, la que ordena que: "un tratado deberá interpretarse de buena fe conforme al sentido corriente que hay a de atribuirse a los términos del tratado en el contexto de éstos y teniendo en cuenta su objeto y fin". Esta regla, a su vez, da aplicación a la norma contenida en el articulo 27 de la misma Convención, según la cual todo tratado en vigor obliga a las partes y debe ser cumplida por ellas de buena fe".

Luego el Tribunal Constitucional en la misma sentencia rol No 804, 
afirma en su considerando 50: "Que, indudablemente, el intérprete en general $y$ el juez en particular debe realizar los mayores esfuerzos, dentro del ámbito constitucional, para procurar cumplir de buena fe las disposiciones y los fines del tratado, conciliando sus disposiciones con otras normas del Derecho Interno, prefiriendo aquellas interpretaciones que armonicen los derechos y obligaciones que del tratado internacional se derivan con el orden jurídico chileno".

El Tribunal Constitucional reiterará en el rol No 804, considerando 12 que la autoridad nacional competente, debe dentro del marco constitucional y de sus atribuciones, materializar en debida forma y de buena fe las obligaciones convencionales: "[...] debe realizar todos los esfuerzos posibles, actuando en el marco de sus atribuciones y en la forma que establece la Constitución, para materializar en debida forma y de buena fe las obligaciones contenidas en ella".

iv) El Tribunal Constitucional en su fallo rol No 804, se pone en la hipótesis de la aplicación del artículo 54 inciso $5^{\circ}$ de la Constitución, el cual determina que "las disposiciones de un tratado sólo podrán ser derogadas, modificadas o suspendidas en la forma prevista en los propios tratados o de acuerdo a las normas generales de Derecho internacional".

El Tribunal Constitucional afirma en su considerando $12^{\circ}$ del fallo que el citado inciso constitucional, "cuyo origen se encuentra en la Constitución española de 1978", le otorga a los tratados una especial protección constitucional, ya que ellos solo pueden ser derogados, modificados o suspendidos de acuerdo a lo determinado por las partes en la respectiva convención internacional o de acuerdo a las normas generales del Derecho internacional, como la Convención sobre Derecho de los tratados (Viena, 1969), a la cual el Estado de Chile ha ratificado, concluyendo que una ley interna contradictoria con un tratado no tiene aptitud de derogarlo, modificarlo o suspenderlo, considerando que dicha ley carece de toda validez, expresando un acto jurídico manifestado en contravención con la Constitución: "reconoce que la derogación, modificación o suspensión de los tratados internacionales ratificados por Chile y que se encuentren vigentes, se realiza en la forma prevista en los propios tratados, esto es, de acuerdo a lo pactado por los concelebrantes, dada su naturaleza convencional, o bien de acuerdo a las normas generales de Derecho internacional, esto es, normas convencionales internacionales que la República de Chile ha ratificado o adherido. Los tratados internacionales ratificados por Chile y que se encuentren vigentes son asi normas jurídicas que gozan de una especial protección constitucional. En tales circunstancias, una ley interna contradictoria con el tratado no tiene la aptitud de derogarlo, modificarlo o suspenderlo, por la simple razón de que carece de toda validez, expresando un acto jurídico que se ha producido en contravención a las formas exigidas por la Constitución".

v) El Tribunal Constitucional en el de su sentencia rol No 804 , conside- 
rando $15^{\circ}$, precisa que ante la existencia de un conflicto entre un tratado y una ley, sin que exista un problema de constitucionalidad de esta última, el tema queda dentro de las atribuciones de los jueces ordinarios los que deben calificar y decidir sobre la materia.

En esta perspectiva, el Tribunal Constitucional determina que es competencia del juez ordinario decidir los conflictos entre tratado y ley, si no hay un problema de constitucionalidad de por medio. "No existe, de esta manera, un problema de constitucionalidad -oposición sustantiva de la ley a la Constitución, sino de contraste entre un tratado internacional vigente y una ley nacional, que corresponde calificar y decidir al juez de la instancia".

Esta decisión del Tribunal Constitucional posibilita a los jueces ordinarios aplicar el control de convencionalidad que exige la Corte Interamericana de Derechos Humanos a los jueces nacionales dando aplicación preferente a los derechos asegurados y garantizados por la Convención americana de derechos humanos y las convenciones complementarias respecto de las leyes internas, cuando ambos entran en conflicto, tal como lo determinó en la sentencia "Almonacid Arellano y otros vs. Chile de 2006"13.

Recordemos que en la materia la Corte Interamericana en el caso señalado determinó en los párrafos 123 a 125, que: "123. La descrita obligación legislativa del artículo 2 de la Convención tiene también la finalidad de facilitar la función del Poder Judicial de tal forma que el aplicador de la ley tenga una opción clara de cómo resolver un caso particular. Sin embargo, cuando el Legislativo falla en su tarea de suprimir y/o no adoptar leyes contrarias a la Convención americana, el Judicial permanece vinculado al deber de garantía establecido en el articulo 1.1 de la misma y, consecuentemente, debe abstenerse de aplicar cualquier normativa contraria a ella. El cumplimiento por parte de agentes o funcionarios del Estado de una ley violatoria de la Convención produce responsabilidad internacional del Estado, y es un principio básico del Derecho de la responsabilidad internacional del Estado, recogido en el Derecho Internacional de los derechos humanos, en el sentido de que todo Estado es internacionalmente responsable por actos u omisiones de cualesquiera de sus poderes u órganos en violación de los derechos internacionalmente consagrados, según el artículo 1.1 de la Convención Americana. 124. La Corte es consciente que los jueces y tribunales internos están sujetos al imperio de la ley y, por ello, están obligados a aplicar las disposiciones vigentes en el ordenamiento jurídico. Pero cuando un Estado ha ratificado un tratado internacional como la Convención Americana, sus jueces, como parte del aparato del Estado, también están sometidos a ella, lo que les obliga a velar porque los efectos de las disposiciones de

${ }^{13}$ Sentencia de la Corte Interamericana de Derechos Humanos, caso "Almonacid Arellano y otros vs. Chile”, de 26 de septiembre de 2006, serie C, $\mathrm{N}^{\circ} 154$. 
la Convención no se vean mermadas por la aplicación de leyes contrarias a su objeto y fin, y que desde un inicio carecen de efectos juridicos. En otraspalabras, el Poder Judicial debe ejercer una especie de "control de convencionalidad" entre las normas juridicas internas que aplican en los casos concretos y la Convención americana derechos humanos. En esta tarea, el Poder Judicial debe tener en cuenta no solamente el tratado, sino también la interpretación que del mismo ha hecho la Corte Interamericana, intérprete última de la Convención Americana. 125. En esta misma linea de ideas, esta Corte ha establecido que '[s]egún el Derecho internacional las obligaciones que éste impone deben ser cumplidas de buena fe y no puede invocarse para su incumplimiento el Derecho interno'. Esta regla ha sido codificada en el artículo 27 de la Convención de Viena sobre el Derecho de los tratados de 1969".

e) Caso en que el Tribunal Constitucional omite pronunciarse sobre violación de derechos esenciales contenidos en tratados internacionales que forman parte del canon de constitucionalidad de disposiciones legales argumentando que estarían en juego consideraciones de mérito.

En sentencia rol 664 de treinta de mayo de 2007, el Tribunal Constitucional debe pronunciarse sobre acción de inaplicabilidad por inconstitucionalidad. Con fecha 23 de noviembre de 2006 el abogado Carlos Hafemann Sepúlveda, en representación de Sergio Pollmann Müller, formula una acción de inaplicabilidad por inconstitucionalidad respecto de diversos artículos del Código de Justicia Militar, del Código Orgánico de Tribunales y de la Ley No 17.798: de Control de Armas, que inciden en la causa rol $N^{\circ}$ 897-1991. Asimismo expresa que se ha visto impedido de recurrir ante un tribunal superior por medio de recursos ordinarios, y en general se encuentra sometido a un proceso discriminatorio, de jurisdicción militar, no obstante no tener calidad de militar, además de sustanciarse una causa paralela por delito conexo, conforme al procedimiento ordinario.

En este caso, el Tribunal Constitucional omitirá toda referencia a los derechos esenciales que constituyen el derecho al debido proceso contenido en el artículo 14 del Pacto internacional de derechos civiles y politicos de Naciones Unidas y al artículo 8 de la Convención americana de derechos humanos, como asimismo, al sentido y alcance de tales derechos esenciales cuyos atributos están asegurados por tales tratados, sobre los cuales existían pronunciamientos claros de la Corte Interamericana de Derechos Humanos, entre los cuales podía contarse el caso "Palamara Iribarne vs. Chile", sentencia de 22 de noviembre de 2005, Serie C, N 135 y en el caso "Almonacid Arellano y otros vs. Chile”, en sentencia de 26 de septiembre de 2006 . Serie C, N 154 , donde la Corte Interamericana, en ambos fallos determinó la responsabilidad internacional del Estado de Chile por violación el artículo $8^{\circ}$ de la conven- 
ción americana de derechos humanos en conexión con la vulneración de las obligaciones generales de respeto y garantía de derechos humanos del art. $1^{\circ}$ de la Convención y la obligación de adecuar su ordenamiento jurídico a través de medidas legislativas o de otro carácter, claramente establecidas en el artículo 2, donde las medidas de otro carácter incluyen las resoluciones judiciales de los tribunales ordinarios y constitucionales en el respectivo ámbito de competencias.

Recordemos algunos párrafos de dichas sentencias de la Corte Interamericana directamente relacionadas con casos chilenos, todas ellas de años anteriores al año de la dictación de la sentencia del Tribunal Constitucional: "En un Estado democrático de Derecho la jurisdicción penal militar ha de tener un alcance restrictivo y excepcional y estar encaminada a la protección de intereses jurídicos especiales, vinculados con las funciones que la ley asigna a las fuerzas militares. Por ello, sólo se debejuzgar a militarespor la comisión de delitos o faltas que por su propia naturaleza atenten contra bienes jurídicos propios del orden militar".

La Corte Interamericana en su parte resolutiva señala: "La Corte concluye que el Estado violó el artículo 8.1. de la Convención, en perjuicio del señor Palamara Iribarne, por haber sido juzgado por tribunales que no tenian competencia para hacerlo, y ha incumplido la obligación general de respetar y garantizar los derechos y libertades dispuesta en el articulo 1.1. de la Convención. Asimismo, al contemplar en su ordenamiento jurídico interno normas contrarias al derecho a ser juzgado por un juez competente protegido por el artículo 8.1. de la Convención, aún vigentes, Chile ha incumplido la obligación general de adoptar disposiciones de Derecho interno que emana del artículo 2 de la Convención"14.

Asimismo, la Corte Interamericana en el caso "Almonacid Arellano y otros vs. Chile” del año 2006, en el cual la sentencia de la Corte Interamericana de Derechos Humanos se había pronunciado claramente, sobre la falta de independencia e imparcialidad de la justicia militar chilena, como asimismo de su falta de legitimidad para juzgar civiles, todo lo cual constituía una grave vulneración de los derechos esenciales contenidos en el artículo $8^{\circ}$ de la convención americana de derechos humanos ${ }^{15}$ : "El tribunal ha señalado que la aplicación de lajusticia militar debe estar estrictamente reservada a militares en servicio activo, al observar en un caso que al tiempo en que se abrió y desarrolló el proceso [en su contra], [la victima tenía] el carácter de militar en retiro, y por ello nopodia serjuzgada por los tribunales militares'. Chile, como Estado democrático,

${ }^{14}$ Corte Interamericana de Derechos Humanos, caso "Palamara Iribarne vs. Chile", sentencia de 22 de noviembre de 2005, serie $\mathrm{C}, \mathrm{N}^{\circ} 135$, párrafo $144^{\circ}$.

${ }^{15} \mathrm{Al}$ respecto véase: Nogueira Alcalá, Humberto, El debido proceso, cit. (n. 12). 
debe respetar el alcance restrictivo y excepcional que tiene la jurisdicción military excluir del ámbito de dicha jurisdicción el juzgamiento de civiles" ${ }^{16}$.

La Corte Interamericana determina, en el mismo caso que: "cuando la justicia militar asume competencia sobre un asunto que debe conocer la justicia ordinaria, se ve afectado el Derecho al juez natural y, a fortiori, el debido proceso, el cual, a su vez, se encuentra intimamente ligado al propio Derecho de acceso a la justicia"17.

El Tribunal Constitucional en la sentencia objeto de análisis orilla el pronunciarse sobre los aspectos sustantivos del debido proceso, por tanto omite el control de convencionalidad que la Corte Interamericana exige a los tribunales chilenos en el mismo caso "Almonacid Arellano vs. Chile", prefiriendo abordar el tema en una arista diferente, el de que este es un problema de mérito, que es de competencia del legislador.

A su vez, busca reforzar su posición respecto de la ilegitimidad que tiene el Tribunal Constitucional para pronunciarse sobre consideraciones de mérito, utilizando para ello jurisprudencia de tribunales constitucionales europeos, el Consejo Constitucional francés y los tribunales constitucionales de España e Italia.

Hay aquí una actividad de funámbulo del Tribunal Constitucional ante un problema espinudo y con un impacto importante en el ámbito político jurídico, la que enmendará y rectificará posteriormente en su sentencia rol No 1845 de control de constitucionalidad sobre la legislación de tribunales militares en 2010, donde asumirá a través de una interpretación conforme a la constitución que los tribunales militares no pueden enjuiciar a civiles.

f) El Tribunal Constitucional en rol $\mathrm{N}^{\circ} 790$, en materia de derecho de igualdad ante la ley y no discriminación utiliza como elemento de interpretación el principio de proporcionalidad.

El requerimiento de inaplicabilidad por inconstitucionalidad respecto de los artículos 4 y 29 de las Leyes $\mathrm{N}^{\circ}$ s. 18.549 y 18.669 , respectivamente, en el proceso rol No 18.828-06, caratulado "Lagos, Hipólito y otros con INP". El requirente sostiene que la aplicación de los aludidos preceptos resulta contraria a los artículos 7,19 , numerales $2^{\circ}, 18^{\circ}, 20^{\circ}, 22^{\circ}, 24^{\circ}$ y $26^{\circ}$, y al artículo 65 de la Constitución Política. Manifiesta que durante los años 1986 y 1987 se dictaron los preceptos impugnados, los que rebajaron una parte del reajuste automático de las pensiones de los demandantes que debía regir desde mayo de 1987 hasta diciembre de 1988, disminuyendo el monto de las mismas. Además destaca que el artículo $4^{\circ}$ de la Ley No 18.549

${ }^{16}$ Corte Interamericana de Derechos Humanos, "caso Palamara Iribarne vs. Chile", sentencia de 22 de noviembre de 2005 , serie $\mathrm{C}, \mathrm{N}^{\circ} 135$, párrafo $139^{\circ}$.

${ }^{17}$ Corte Interamericana de Derechos Humanos, "caso Almonacid Arellano y otros vs. Chile”, sentencia de fecha 26 de septiembre de 2006, párrafo $131^{\circ}$. 
de 1986, estableció que las disminuciones se debían aplicar por una sola vez en el año 1987, en forma excepcional y a título de reajuste sustitutivo. Según el actor, lejos de respetarse lo dispuesto en la propia ley, las rebajas a las pensiones de sus representados no sólo operaron durante los años 1987 y 1988 sino que siguieron descontándose en las pensiones de los siguientes años y hasta la fecha, con lo cual se disminuyó inconstitucional e ilegalmente el monto de las mismas.

El requirente estima vulnerado el artículo 19 No 22 de la Carta Fundamental, que consagra la prohibición de que el Estado y sus organismos establezcan discriminaciones arbitrarias en materia económica. Atribuyendo a los reajustes de pensiones el carácter de una "materia económica”, señala que, al dictar las normas legales impugnadas, el legislador ha actuado en forma desigualitaria y arbitraria. Agrega que aun cuando se haya impuesto un tratamiento económico especial a los jubilados que representa, en virtud de una ley, ella no obedece a los parámetros de racionalidad y justicia que exige la norma constitucional mencionada. Precisa que el contenido de las leyes con el fin de que sea igual o desigual para todos los que se encuentran en la misma situación fáctica debe determinarse exclusivamente en función de la justicia.

El Tribunal Constitucional reconoce que entre los diversos grupos de pensionados señalados en los preceptos legales existen diferencias: "Vigésimo: Que sobre la base de lo expresado es posible constatar que entre los diferentes grupos depensionados mencionados en los preceptos legales impugnados existen diferencias, pues aquellos que no se encontraban en los supuestos descritos en el considerando precedente si pudieron recibir el 100\% de reajuste de la pensión respectiva conforme a la variación experimentada por el Indice de Precios al Consumidor. La constatación de la diferencia anotada resulta fundamental para realizar el examen de constitucionalidad que pretenden los requirentes, pues como ha precisado el Tribunal Constitucional español, "lo propio del juicio de igualdad es que ha de constatarse siempre mediante un criterio de carácter relacional que, cuando se proyecta sobre el legislador requiere como presupuesto obligado la previa comprobación de que, como consecuencia de la medida legislativa impugnada, se ha introducido directa o indirectamente una diferencia de trato entre personas. Sólo verificado este primer presupuesto se procederá a determinar la licitud constitucional o no de la diferencia contenida en la norma" (sentencia 253/2004).

Determinadas las diferencias de trato introducidas por la ley, el Tribunal Constitucional razona sobre si ellas se ajustan al orden constitucional: "Vigésimo primero: Que, constatado que los preceptos legales impugnados efectivamente introdujeron diferencias de trato entre las distintas categorias de pensionados reguladas por ellos, resulta necesario determinar si esas diferencias 
son constitucionalmente tolerables de acuerdo a lo preceptuado por el artículo $19 N^{\circ} 2$ de la Carta Fundamental, que probibe, precisamente, al legislador y a toda otra autoridad 'establecer diferencias arbitrarias"”.

Para realizar este análisis, el Tribunal Constitucional recurre a los criterios básicos sobre igualdad ante la ley, como es el criterio de razonabilidad de la diferencia: "En tal sentido útil resulta recordar que, en reiterados pronunciamientos, este Tribunal ha hecho suyas las expresiones del constitucionalista argentino Segundo Linares Quintana, que sostiene que "la igualdad ante la ley consiste en que las normas juridicas deben ser iguales para todas las personas que se encuentren en las mismas circunstancias y, consecuencialmente, diversas para aquellas que se encuentren en situaciones diferentes. No se trata, por consiguiente, de una igualdad absoluta sino que ha de aplicarse la ley en cada caso conforme a las diferencias constitutivas del mismo. La igualdad supone, por lo tanto, la distinción razonable entre quienes no se encuentren en la misma condición". Por lo tanto, concluye, "la razonabilidad es el cartabón o standard de acuerdo con el cual debe apreciarse la medida de igualdad o la desigualdad" (Sentencias roles No 28, 53 y 219).

El Tribunal Constitucional, luego de considerar la razonabilidad de la norma legal, asume la necesidad de que la diferencia se base en un criterio objetivo y un bien jurídico constitucional, como asimismo en los principios de adecuación y proporcionalidad en sentido estricto, apoyándose en la jurisprudencia de la Corte Suprema de México, además de mencionar sin entrar al análisis específico de fallos de los tribunales constitucionales de España y de Alemania: "Vigésimo segundo: Que el examen de la jurisprudencia de diversos Tribunales Constitucionales, como el español y el alemán, da cuenta de que no basta, sin embargo, que la justificación de las diferencias sea razonable sino que además debe ser objetiva. La Suprema Corte de Justicia de México concuerda con este criterio cuando señala que 'Si bien el emisor de la norma puede prever situaciones fácticas que requieren un trato diferente, este debe sustentarse en criterios razonables y objetivos que lo justifiquen, sin dejarlo al capricho o voluntad del legislador'. Por su parte, la Suprema Corte de México precisa que, para los efectos de considerar si, en un caso concreto, una discriminación está totalmente vedada, debe determinar, 'en primer lugar', si la distinción legislativa obedece a una finalidad objetiva y constitucionalmente válida: el legislador no puede introducir tratos desiguales de manera arbitraria, sino que debe hacerlo con el fin de avanzar en la consecución de objetivos admisibles dentro de los limites marcados por las previsiones constitucionales, o expresamente incluidos en ellas. En segundo lugar, es necesario examinar la racionalidad o adecuación de la distinción hecha por el legislador: es necesario que la introducción de una distinción constituya un medio apto para conducir al fin u objetivo que el legislador quiere alcanzar, es decir, que exista una relación 
de instrumentalidad entre la medida clasificatoria y el fin pretendido. En tercer lugar, debe cumplirse con el requisito de la proporcionalidad: el legislador no puede tratar de alcanzar objetivos constitucionalmente legitimos de un modo abiertamente desproporcional, de manera que el juzgador debe determinar si la distinción legislativa se encuentra dentro del abanico de tratamientos que pueden considerarse proporcionales, habida cuenta de la situación de hecho, la finalidad de la ley y los bienes y derechos constitucionales afectados por ella [...]. Por último, es de importancia determinar en cada caso respecto de qué se está predicando con la igualdad [...]" (sentencia $\mathrm{N}^{\circ}$ 988/2004, en Semanario Judicial de la Federación y su Gaceta, Tomo XX, diciembre de 2004, p. 362)".

El Tribunal Constitucional introduce así el postulado o principio de proporcionalidad para analizar la conformidad de la norma legal restrictiva del Derecho a la igualdad, sin embargo, elige una sentencia mexicana que no es la más adecuada, ya que dicha sentencia olvida considerar el segundo subprincipio del postulado de proporcionalidad que es el que la medida restrictiva legislativa sea estrictamente necesaria, ya que si hay otra medida que logre el mismo objetivo afectando menos el Derecho es esta última la que debe aplicarse.

A su vez, es curioso que el Tribunal Constitucional se vaya al análisis de la jurisprudencia comparativa y no se refiera a la jurisprudencia de la Corte Interamericana de Derechos Humanos, la cual sí constituye un elemento necesario de considerar en virtud de la vinculación y obligatoriedad de aplicación que tienen los tribunales nacionales en relación a la Convención Americana de Derechos Humanos, en especial respecto de la igualdad ante la ley y el principio de no discriminación, que se considera por la Corte Interamericana como principio imperativo de Derecho internacional ${ }^{18}$, donde hay una abundante jurisprudencia y una línea jurisprudencial sostenida en el tiempo como estándar mínimo de obligatorio cumplimiento para los Estados partes de la Convención. Al respecto pueden mencionarse las Opiniones Consultivas $\mathrm{N}^{\circ} 4 / 1984$ de enero de 1984 y N ${ }^{\circ} 18 / 03$, de fecha 17 de septiembre de 2003; y las sentencias en el caso de las niñas "Yean y Bosico vs. República Dominicana”, sentencia de 8 de septiembre de 2005; Caso "Yatama vs. Nicaragua", sentencia de 23 de junio de 2005; caso "López Álvarez vs. Honduras", sentencia de 1 de febrero de 2006.

El Tribunal Constitucional realizará así el análisis de los subprincipios del principio de proporcionalidad, incluyendo el subprincipio de necesidad, sin precisar ni justificar el tipo e intensidad del control que concretará, haciendo alusión a una sentencia de la Corte Constitucional de Colombia que no analiza y que no es posible determinar si la situación considerara es

\footnotetext{
${ }^{18}$ Corte Interamericana de Derechos Humanos, "caso López Álvarez vs. Honduras”, sentencia de $1^{\circ}$ de febrero de 2006 , serie C, № 141 , párrafo $170^{\circ}$.
} 
análoga o no, la afirmación carece así del rigor necesario del análisis de la jurisprudencia comparada: "Vigésimo tercero: Que, en el presente caso, los articulos $4^{\circ}$ de la Ley $N^{\circ} 18.549$ y 29 de la Ley $N^{\circ} 18.669$ impidieron que, durante los años 1986 y 1987, los pensionados que recibian pensiones que superaran los $\$ 43.500$ y los $\$ 47.850$, respectivamente, recibieran el reajuste del $100 \%$ de la variación del Índice de Precios al Consumidor, que correspondia aplicar al cumplirse los supuestos previstos por los Decretos Leyes $N^{\circ}$ s. 2.448 y 2.547, ambos de 1979, reduciendo, en cambio, dicho reajuste de acuerdo a las pautas que esas mismas normas indicaron. Cabe advertir que la aplicación de tales criterios implicó que los pensionados respectivos recibirian un porcentaje menor del reajuste anunciado, pero, en ningún caso, que quedarian desprovistos de él. "Vigésimo cuarto: Que, al tenor de lo precisado y, especialmente, teniendo presente la historia legislativa de los preceptos impugnados en esta oportunidad, no puede calificarse de arbitraria una medida que, como la reflejada en los artículos $4^{\circ}$ de la Ley $N^{\circ} 18.549$ y 29 de la Ley $N^{\circ} 18.669$, tuvo por objeto "moderar en el gasto fiscal" una consecuencia presupuestaria de envergadura como la necesidad de destinar 9 mil quinientos millones de pesos al reajuste de pensiones desatendiendo, en caso de pagarse integra esa cantidad, otras politicas y programas sociales en que el Estado se encontraba comprometido. Lo anterior no solamente resulta ajustado a la razón, pues el Estado tiene el deber de "contribuir a crear las condiciones sociales que permitan a todos y a cada uno de los integrantes de la comunidad nacional su mayor realización espiritual y material posible", según ordena el artículo $1^{\circ}$, inciso cuarto, de la Constitución, sino que constituye un fundamento dotado de suficiente objetividad, pues las dificultades presupuestarias por las que atraviesa cualquier Estado suelen estar rodeadas de adecuada cobertura informativa, de modo que pueden ser fácilmente conocidas por toda la población; Vigésimo quinto: Que, desde esa misma perspectiva, la finalidad perseguida por el legislador, en el caso de los preceptos legales reprochados, resulta adecuada y necesaria, pues no parece posible beneficiar integralmente a un sector de la población sobre la base del sacrificio de otros que también requieren atención de parte de un Estado que es esencialmente subsidiario en nuestra concepción constitucional. Por lo demás, como lo ha fallado la Corte Constitucional de Colombia, ante requerimientos similares al de la especie, "ese tratamiento distinto ante situaciones iguales, a la luz de los cánones constitucionales, tiene una justificación clara y razonable, cual es la de dar especial protección a aquellos pensionados que por devengar una pensión minima se encuentran, por razones económicas, en situación de debilidad manifiesta ante los demás" (sentencia C-387-94). Asi, existe una situación objetiva y razonable de diferencia entre aquellos pensionados que recibian una pensión inferior a $\$ 43.500$ y a $\$ 47.850$, de conformidad con cada uno de los preceptos legales impugnados, que tuvieron derecho a que sus pensiones 
se les pagaran reajustadas en el 100\% de la variación del Índice de Precios al Consumidor, y aquellos que, como los requirentes, estaban en condiciones de soportar una disminución del reajuste originalmente anunciado -que llegó incluso al 50\%-por percibir montos superiores de pensión".

3. Análisis sobre uso del Derecho constitucional extranjero y jurisprudencia constitucional extranjera.

a) El Tribunal Constitucional utiliza el Derecho constitucional extranjero y la jurisprudencia de tribunales o cortes extranjeras generalmente como reforzamiento de la argumentación desarrollada.

i) El Tribunal Constitucional en sentencia rol $\mathrm{N}^{\circ} 549$ de treinta de marzo de 2007, razona sobre el principio de tipicidad en materia penal y acude a jurisprudencia del Tribunal Constitucional español.

El Tribunal Constitucional resuelve requerimiento presentado por la Segunda Sala del Tribunal Oral en lo Penal de Concepción, la cual oficia al Tribunal Constitucional a fin de requerir un pronunciamiento sobre la aplicabilidad del artículo 434 del Código Penal, a la luz del principio de tipicidad consagrado en el artículo $19 \mathrm{~N}^{\circ} 3$ de la Constitución, que incide en la causa RIT No 130-2006, sobre piratería, que se sigue ante el tribunal del juicio oral en lo Penal de Concepción.

El Tribunal Constitucional razona sobre el principio de tipicidad y refuerza su argumentación apelando a la jurisprudencia del Tribunal Constitucional español: "En tal sentido, el Tribunal Constitucional español, en sentencia $N^{\circ} 89$, de 12 demarzo de 1993, ha precisado lo siguiente: 'Es claro que el legisladorpenal no viene constitucionalmente obligado a acuñar definiciones especificas para todos y cada uno de los términos que integran la descripción del tipo. Si se tiene presente lo que queda dicho en el fundamento que antecede -esto es, la inserción de toda norma en el sistema que es el ordenamiento-, una tal labor definitoria sólo resultaría inexcusable cuando el legislador se sirviera de expresiones que por su falta de arraigo en la propia cultura jurídica carecieran de toda virtualidad justificante y deparasen, porlo mismo, una indeterminación sobre la conducta delimitada mediante tales expresiones"'.

ii) En sentencia rol 523 de diecinueve de junio de 2007, el Tribunal Constitucional utiliza la jurisprudencia constitucional española para reforzar su argumentación sobre la autonomía universitaria.

Don Jaime Reyes Saavedra, en representación de Viviana Graciela Parra Miranda y otros, presenta un requerimiento de inaplicabilidad por inconstitucionalidad respecto del texto completo del Decreto con Fuerza de Ley No 153 de 1981, del Ministerio de Educación -Estatuto de la Universidad de Chile-, y, en especial, de sus artículos $4^{\circ}$ y 12 , letras c) y h); del artículo 
2 de la Ley No 18.663, interpretativa del artículo 12, letra h), del Decreto con Fuerza de Ley citado precedentemente y del texto completo del Decreto con Fuerza de Ley № 29, de 2004, del Ministerio de Hacienda, que fija el texto refundido, coordinado y sistematizado de la Ley No $18.834-$ Estatuto Administrativo-, y, en especial, de su artículo 154. La declaración de inaplicabilidad se pide por cuanto el requirente estima que todos los cuerpos normativos impugnados habrían servido como fuentes habilitantes para que el rector de la Universidad de Chile dictara, al margen de lo establecido en los artículos 65 inciso $4^{\circ}$, $\mathrm{N}^{\circ} 2^{\circ}$ y $7^{\circ}$ de la Constitución Política, el Decreto Universitario $\mathrm{N}^{\circ} 415$, de 19 de enero de 2006, que, junto con reestructurar el Liceo Experimental Manuel de Salas, dependiente de esa Casa de Estudios Superiores, ordenó la supresión de los cargos que servían sus representados en dicho establecimiento educacional.

El Tribunal en su considerando décimo cuarto, determina el ámbito y extensión de la autonomía universitaria: "Que la autonomia universitaria, en tanto autonomía máxima o extensiva, comprende al menos tres aspectos esenciales y ligados indisolublemente: el académico, el económico y el administrativo. El primero dice relación con la potestad para determinar la forma en que deben realizar sus funciones fundamentales de docencia, investigación y extensión. A su turno, la autonomía económica apunta a la potestad soberana de determinar la forma en que se distribuye su presupuesto para cumplir sus fines esenciales. Por último, la autonomia administrativa dice relación con la facultad para organizar su funcionamiento interno de manera eficiente para satisfacer adecuadamente sus servicios. Asi se ha reconocido, entre otras normas, por la Constitución de 1925, modificada, el año 1970, a través de la Ley $N^{o}$ 17.398 y actualmente por el articulo 75 de la Ley Orgánica Constitucional de Enseñanza, declarado constitucional por esta Magistratura (rol $N^{\circ} 102$, de 27 de febrero de 1990). Ciertamente, el objetivo de la autonomía académica $y$ administrativa es precisamente asegurar el ejercicio de la total autodeterminación docente e institucional de las universidades, que constituye uno de los valores fundamentales de toda sociedad democrática".

En el considerando décimo quinto, el Tribunal Constitucional, analiza el contenido de la autonomía administrativa de las universidades, determinando en su considerando décimo séptimo que: "en cuanto a la autonomía administrativa de las universidades estatales, cabe tener presente lo dispuesto en el artículo 32 de la Ley Orgánica Constitucional de Bases Generales de la Administración del Estado, que dispone que 'las instituciones de Educación Superior de carácter estatal podrán, además, establecer en su organización Facultades, Escuelas, Institutos, Centros de Estudios y otras estructuras necesarias para el cumplimiento de sus fines especificos'. Dich a disposición, tácitamente, lasfaculta para crear nuevasplantas de funcionarios y, consecuentemente, para 
suprimir los cargos que en ellas se sirven. En tal sentido, cabe tener presente que sobre esta disposición y a habia sostenido esta Magistratura, en su sentencia rol No 352, 'que, como puede apreciarse, la Ley $N^{\circ} 18.575$, teniendo presente su naturaleza propia y la importancia que para las instituciones estatales de Educación Superior tiene el contar con autonomia, se las atribuyó expresamente en la forma que en dicha disposición se establece”" (considerando No 17).

Para precisar en su considerando vigésimo que: "Que un razonamiento sustentado en lo precedentemente enunciado obliga a entender como inherente a la organización y funcionamiento corporativos o a la fijación de sus plantas, el disponer de los empleos. De otro modo, es dificil entender el nombramiento de personal sin contar con plazas vacantes o libres, o la posibilidad de reestructurar la planta sin tener atribuciones para efectuar alteraciones en ella, tanto en su composición como en el número y funciones asignadas al personal que la integra".

En los considerandos vigésimo primero y vigésimo séptimo, el Tribunal reconoce la fuente constitucional de la autonomía universitaria y su carácter de garantía institucional de la libertad de enseñanza: "Que, sin perjuicio de lo anteriormente señalado, debe tenerse presente que la autonomía universitaria tiene fundamento en la autonomia de los cuerpos intermedios, reconocida en el artículo $1^{\circ}$, inciso tercero, de la Constitución Política de la República. Que, del mismo modo, la autonomía universitaria tiene además fundamento en sede constitucional, toda vez que constituye la garantía institucional de la libertad de enseñanza, tutelada en el artículo $19 N^{\circ} 11$ de la Constitución Política de la República”.

Finalmente el Tribunal utiliza la jurisprudencia del Tribunal Constitucional español para reforzar su línea argumental sobre sentido y alcance de la autonomía universitaria: "Que, por último, asi lo ha señalado también la jurisprudencia extranjera. Al efecto, el Tribunal Constitucional español ha precisado que el fundamento y justificación de la autonomia universitaria debe vincularse con 'el respeto a la libertad académica, es decir, a la libertad de enseñanza, estudio e investigación'. De este modo, 'la protección de estas libertades frente a las injerencias externas constituye la razón de ser de la autonomía, la cual requiere, cualquiera que sea el modelo organizativo que se adopte, que la libertad de ciencia sea garantizada tanto en su vertiente individual cuanto en la colectiva de la institución', y agrega que 'la autonomía universitaria tiene como justificación asegurar el respeto a la libertad académica, es decir, a la libertad de enseñanza y de investigación. Más exactamente, la autonomia es la dimensión institucional de la libertad académica que garantiza y completa la dimensión individual, constitucionalizada, de la libertad de cátedra" (STC 26/1987)".

iii) El Tribunal Constitucional en su sentencia rol $N^{\circ} 616$, utiliza un 
criterio afirmado en una línea jurisprudencial sostenida en el tiempo, a través de la cual afirma que las materia de mérito corresponden al legislador y que el Tribunal Constitucional en cuanto órgano de control de constitucionalidad solo actúa como órgano de control de constitucionalidad no correspondiéndole evaluar el mérito de las disposiciones legales.

El Tribunal Constitucional en esta sentencia reafirma su línea jurisprudencial ya desarrollada en sentencias anteriores que menciona: "cuando el Congreso Nacional excede su ámbito de atribuciones, infringiendo los márgenes contemplados en el texto, principios o valores esenciales de la Carta Fundamental, o violente el proceso de formación de la ley, el Tribunal Constitucional puede intervenirpara reparar los vicios de inconstitucionalidad en que éste haya incurrido (Vid. entre otros, rol $N^{\circ} 664 / 2006$, consid. 22 $2^{\circ}$ ).

El Tribunal reitera dicha idea: "[...] esta Corte ha afirmado que "el Tribunal Constitucional no legisla ni administra, ni entra a calificar la bondad de las disposiciones legales o administrativas sometidas a su control."

A su vez, el Tribunal Constitucional refuerza su perspectiva de no involucrarse en materia de mérito de la decisión legislativa acudiendo a la jurisprudencia constitucional europea de las cortes constitucionales de Francia, España, y Alemania, en su considerando cuadragésimo tercero: "Que dicho principio constituye una regla básica adoptada explícitamente por los más importantes Tribunales Constitucionales de Europa. Asi, por ejemplo, el Consejo Constitucional francés ha declarado su incompetencia para emitir pronunciamientos sobre cuestiones de mérito, consignando que "la Constitución no le confiere al Consejo Constitucional un poder general para juzgar y decidir idéntico a aquél del Parlamento. Sólo le entrega competencia para decidir si una ley sometida a su control es consistente o no con la Constitución"; concluyendo el Tribunal galo -en el ámbito de una modificación a la ley penal-que "dentro de los márgenes de su misión, no le cabe al Consejo Constitucional reemplazar el juicio del Parlamento por el propio con respecto a la necesidad de las penas impuestas a los delitos' (Vid. David Dokhan, Les limites du contròle de la constitutionnalité des actes législatifs", 2001, Librairie Générale de Droit et de Jurisprudence, especialmente páginas $450 \mathrm{y}$ siguientes). El Tribunal Constitucional español, por su parte, ha precisado que: 'La Constitución, como marco normativo, suele dejar al legislador márgenes más o menos amplios dentro de los cuales aquél puede convertir en Ley sus preferencias ideológicas, sus opcionespoliticas y sus juicios de oportunidad'. Explicando dicho espacio de libertad legislativa, el Tribunal hispano ha añadido que: 'El legislador es libre dentro de los limites que la Constitución establece, para elegir la regulación de tal o cual Derecho o institución juridica que considere más adecuada a sus preferenciaspoliticas. Quien no puede dejarse llevar a este terreno es el Tribunal Constitucional. Como ha indicado la doctrina hispana 'el juicio del Tribunal 
se ha de circunscribir asi a determinar la conformidad con la Constitución de la Ley impugnada. No es, por tanto, un juicio de valor acerca de si la regulación adoptada es o no la más oportuna, porque éste es el campo de actuación en que han de moverse las distintas opciones políticas dentro del marco de la Constitución' (Francisco Fernández Segado, El sistema constitucional español, 1992, p. 1085). En el mismo sentido, en Alemania, se ha precisado que 'mientras no se oponga a mandatos o probibiciones constitucionales, el Parlamento es libre en el empleo de sus facultades legislativas de configuración, en la determinación de prioridades y en el recurso a medios presupuestarios; igualmente libre es el Gobierno en su politica interior y exterior o la Jurisdicción a la hora de interpretar y aplicar el Derecho ordinario. El Bundesverfassungsgericht no es competente para examinar si cualquiera de tales órganos ha observado adecuadamente sus responsabilidades o ha dado con la fórmula de solución más justa' (Helmut Simon, La Jurisdicción Constitucional, en Manual de Derecho Constitucional, varios autores, 1996, p. 851). De este modo, como lo ha consignado el Tribunal Constitucional alemán, el legislador goza de un espacio de reglamentación, valoración y examen propio que, en principio, no puede ser revisado por los tribunales (sentencia de la Segunda Sala, 29 de octubre de 1987, Tomo 77, página 170 II, en "50 años de Jurisprudencia del Tribunal Constitucional Federal Alemán”, Jürgen Schwabe, 2003, p. 92). Por último, en el caso de Italia, el principio de la autonomia legislativa ha sido reconocido expresamente por la normativa que reglamenta las funciones del Tribunal Constitucional, particularmente el artículo 28 de la Ley 87, del 11 de marzo de 1953, que veda a dicho órgano de control constitucional "cualquier valoración de naturaleza politica y cualquier control sobre el uso del poder discrecional del Parlamento".

iv) En sentencia rol № 796, de once de diciembre de dos mil siete, los ministros disidentes utilizan doctrina y jurisprudencia constitucional española para reforzar su tesis acerca de la garantía institucional de la autonomía municipal que se habría lesionado por el legislador en este caso concreto.

Que con fecha 6 de junio de 2007, Carlos López Vega, alcalde de la Municipalidad de Sierra Gorda, ha formulado una acción de inaplicabilidad por inconstitucionalidad respecto del artículo 11 del decreto Ley $\mathrm{N}^{\circ} 799$, de 1974, en relación al recurso de apelación que ha deducido contra la resolución No 021, de 3 de enero de 2007, de la Contraloría General de la República, por infracción al citado cuerpo normativo, rol de ingreso No 2237-2007, caratulado "Carlos López Vega".

El Tribunal Constitucional rechaza el requerimiento planteado.

Sin embargo, los votos disidentes de los Ministros José Luis Cea Egaña y Marcelo Venegas Palacios hacen alusión a la garantía institucional de la autonomía local, considerando doctrina y jurisprudencia del Tribunal 
Constitucional español: "9. Siguiendo a Luis Cosculluela Montaner, en su Manual de Derecho Administrativo, afirmamos que la autonomia municipal comprende distintos aspectos. Desde luego, el reconocimiento de una esfera de intereses propios y la atribución de competencias para su gestión. Aunque tales competencias no se hallen establecidas en la Constitución y se dejen a la determinación del legislador ordinario, no puede éste reducirlas a límites tales que tornen imposible satisfacer los intereses que la Constitución les confia. (Asi lo decidió el Tribunal Constitucional de España en sentencias 4/1981, de 2 de febrero, 32/1981, de 29 de julio, y 214/1989, de 21 de diciembre). La garantía constitucional de la autonomia local también implica la auto selección de sus órganos de gobierno, y su capacidad para representar y gobernar los intereses de la comunidad que integra estas entidades. Se trata de afirmar el principio democrático y el carácter politico de las elecciones locales. Por último, la autonomía supone atribuir a las entidades locales el poder de ordenanza, esto es, la capacidad de dictar normas, aunque de simple rango reglamentario".

Dicha referencia al Derecho español les permitirá a los disidentes reforzar su posición sobre la autonomía municipal en el ordenamiento constitucional chileno, lo que sostendrán en los considerandos de su voto que se señalan a continuación: "10. En su texto original de 1980, el artículo 118, inciso tercero actual, entonces articulo 107, inciso cuarto, de la versión precedente, no atribuia a los municipios, en términos explícitos, la calidad de entes autónomos. Sin embargo, lo ya demostrado deja de relieve que era tan nitida es a caracteristica que la jurisprudencia tampoco tuvo duda para reconocerla. Insertamos en seguida parte de la sentencia de este Tribunal, rol $N^{\circ} 80$, fechada el 22 de septiembre de 1989, porque deja de manifiesto lo expuesto: ' 5 '. Que si bien es cierto que la Constitución, en su artículo 107 (hoy 118), no dice expresamente que las Municipalidades son entes autónomos, su autonomía se infiere del propio texto constitucional, al establecer que las Municipalidades son corporaciones de Derecho público, con personalidad jurídica y patrimonio propios, y que sus atribuciones las derivan directamente de su ley orgánica constitucional. De acuerdo con la disposición mencionada es clara la autonomía constitucional de estos órganos, pues se trata de entes personificados que ha creado el Estado en el propio texto constitucional y cuyas atribuciones no las reciben del Poder Central, sino que de la ley orgánica constitucional. [...]. Las Municipalidades son órganos descentralizados territorialmente, generados por la Constitución y que actúan con su propia personalidad jurídica de Derecho público y con patrimonio propio, por lo que, a juicio de este Tribunal, serian órganos constitucionalmente autónomos, $y$ las controversias en que incurran con otras entidades no pueden ser resueltas por autoridades administrativas dependientes del Poder Ejecutivo, pues ello significaría violar la autonomia que nuestro ordenamiento constitucional les ha otorgado./ Lógicamente deducible de lo transcrito es que, al incorporar el Poder 
Constituyente, esta vez expresamente, la autonomía de los municipios como uno de sus rasgos caracteristicos, mediante la reforma introducida por la Ley $N^{\circ}$ 19.097, de 12 de noviembre de 1991, lo hizo para fortalecerla, despejando asi toda pretensión de someterlos a otros órganos con infracción de lo previsto en la Carta Politica o en las leyes que la complementan'./ 11. Si se respeta la Constitución en su espiritu y letra, como lo bemos puntualizado, nadie puede sostener que la autonomía sea susceptible de entenderse como sinónimo de independencia ni con el significado de potestad soberana en el área territorial de la comuna. Pero de la relatividad del principio, determinada por su naturaleza intrinseca y las finalidades especificas que ha de servir, no se sigue licencia para desconocerlo, v.gr., admitiendo injerencias extrañas al municipio con base en la interpretación extensiva de leyes comunes o, peor todavia, infundiendo jerarquia de normas orgánico-constitucionales a las que carecen de esa naturaleza y jerarquía. Tal es, no cabe duda, el caso del Decreto ley $N^{\circ} 799$ de 1974, cuyo articulo 11, en si y también a raiz de la interpretación que se le ha otorgado por la Contraloría General de la República, a juicio de los disidentes vulnera cuanto exige e implica la autonomía de los municipios".

b) El Tribunal Constitucional utiliza el Derecho constitucional o la jurisprudencia constitucional extranjera para desarrollar clasificación de modelos de diversas instituciones jurídicas mediante la confrontación de ordenamientos jurídicos.

En sentencia rol No 616 de 6 de septiembre de 2007, el Tribunal Constitucional considera información comparativa de diversos países con distintas familias de sistemas jurídicos, para afirmar la existencia de distintos modelos institucionales de justicia administrativa, lo que le permitirá sostener que en la materia existe un ámbito de discrecionalidad del legislador que no produce un problema de constitucionalidad.

En efecto, en este caso, la parte requirente formula una acción de inaplicabilidad por inconstitucionalidad respecto de los artículos 6 letra b) y 115 del Código Tributario, así como también del artículo 19 letra b) del Decreto con fuerza de ley No 7 de 1980: Ley Orgánica del Servicio de Impuestos Internos. Esta parte señala que a raíz de una fiscalización tributaria, el Servicio de Impuestos Internos determinó que habría incurrido en faltas al Decreto ley No 1974, por lo cual se formuló reclamo contra la liquidación decretada.

Como señala el mismo Tribunal Constitucional: "el conflicto constitucional se encuentra centrado en la circunstancia de que el requirente estima que los preceptos legales que le otorgan jurisdicción y competencia al Director Regional del Servicio de Impuestos Internos en materia de reclamos tributarios infringirian la Constitución Politica de la República, desde el momento que para que exista un tribunal, éste debe cumplir con dos exigencias minimas como son la independencia y la imparcialidad, presupuestos esenciales del debido 
proceso, que no se darian en la especie, todo lo cual sin embargo es refutado por la recurrida de autos".

El Tribunal Constitucional hace un análisis de Derecho comparado en su considerando vigésimo sexto, para establecer las distintas modalidades de justicia administrativa en Inglaterra, Alemania, España, Argentina, Bolivia, Brasil, Costa Rica, Chile, Ecuador, Guatemala México, Paraguay, Perú, y Venezuela, como asimismo las propuestas formuladas por el Código tributario modelo para América Latina, además de afirmaciones de doctrina sobre lo que ha considerado la jurisprudencia norteamericana, sin ninguna referencia directa a ella. Dice: "Que en materia de la denominada justicia contenciosa administrativa existen diversas modalidades y vertientes, en estricta concordancia con la tradición juridica de cada uno de los paises. Asi, la tradición francesa se origina con un fuerte énfasis en la resolución de los conflictos a través de órganos más bien de corte administrativo, particularmente, el Consejo de Estado. De este modo, se explica, el otorgamiento de funciones de carácter jurisdiccional a órganos que forman parte del Ejecutivo. En Inglaterra, en cambio, estas controversias están entregadas al conocimiento - en general-de los tribunales ordinarios. Alemania, a su turno, ha establecido una jurisdicción especial contenciosa administrativa situada fuera del Poder Judicial, mientras que en España forma parte de este último. Sin embargo, en el curso del siglo XX se han producido interacciones entre dichos modelos. Asi, 'mientras que en Francia se comienza por entregar la resolución del contencioso administrativo a cuerpos administrativos que vienen a alcanzar paulatinamente un pleno o cuasi pleno carácter jurisdiccional, con sus correspondientes garantias, en Inglaterra el original sistema de control por tribunales ordinarios empieza a ser desplazado por la atribución de conocimiento de contenciosos administrativos especiales a órganos administrativos, sometidos en última instancia sólo a un control político' (Eduardo Aldunate Lizana, La evolución de la justicia administrativa, en "La Justicia Administrativa, 2005, p. 15). Incluso, la jurisprudencia estadounidense no ha estimado como contrario a la Carta Fundamental el que entidades administrativas puedan conocer ciertos contenciosos administrativos, exigiendo si que el ciudadano pueda impugnar lo resuelto ante los tribunales de justicia (V. Vigoriti, Constituzione e Giusticia Amministrativa negli Stati Uniti D’America, en Rivista Trimestrale di Diritto Pubblico, 1970, cit. por Andrés Bordalí Salamanca, Principios de una nueva justicia administrativa en Chile, en Justicia Administrativa, p. 348). En Hispanoamérica, por su lado, se observan diversas variantes en el contencioso tributario, según lo consigna el jurista uruguayo Ramón Valdés Costa ("Instituciones de Derecho Tributario, Depalma, 1992). Asi, en primer lugar, en ciertos países como Argentina, Costa Rica, México, Perú y Chile, se advierte la existencia de tribunales fiscales administrativos. En Brasil, Paraguay 
y Venezuela se han establecido tribunales judiciales especializados en el seno del Poder Judicial.Del mismo modo, en Bolivia, Ecuadory Guatemala se han instituido tribunales independientes. Por último, en Colombia y Uruguay se ha otorgado competencias en estas materias al Consejo de Estado y al Tribunal Contencioso Administrativo, respectivamente, como entes autónomos. En tal sentido, debe hacerse presente que el Código Tributario Modelo para América Latina, insta a que la función jurisdiccional quede "reservada a órganos especializados judiciales, pero todos con la caracteristica común fundamental de ser independientes de la administración activa";

El Tribunal Constitucional, en el considerando vigésimo séptimo, sigue razonando a través de la doctrina de algunos autores argentinos y chilenos, sobre la materia: "Que, como puede observarse, aunque se trata de una tendencia en retirada y fuertemente cuestionada, es del caso tener presente que como lo señala un destacado administrativista trasandino 'tanto en Chile como en Argentina se ha admitido el ejercicio de potestades jurisdiccionales a favor de órganos administrativos en razones de especialidad funcional' (Juan Carlos Cassagne, La justicia administrativa en Iberoamérica, en "La Justicia Administrativa", 2005, p. 22). En Argentina, cabe tenerpresente, que la Corte Suprema ha señalado que la facultad de los entes administrativos para juzgar no atenta con el debido proceso y el Derecho a la defensa, en tanto el afectado pueda recurrir ante el Poder Judicial, de modo de revisar lo fallado ("César y Antonio Karma SCICA", Fallos, 310:360, citado por Néstor Pedro Sagües, Elementos de Derecho Constitucional, Tomo II, 1999, página 761). Como lo consigna Silva Cimma, se trata de órganos de la administración activa, dotados de 'funciones jurisdiccionales respecto de ciertas y determinadas materias que les han sido expresamente encargadas por la ley. Asi, ejercen esta función, en determinados casos, el Director General de Aduanas, el Director General de Impuestos Internos' (Derecho Administrativo Chileno y Comparado. Introducción y Fuentes, 1996, p. 33)".

Todo ello permite concluir al Tribunal Constitucional sobre la posibilidad de que en el ordenamiento jurídico chileno la autoridad administrativa puede ejercer funciones de carácter jurisdiccional, como precisa en su considerando vigésimo noveno, ya que ello es una opción legítima que puede adoptar el legislador en virtud de sus apreciaciones de mérito sobre la matera.

Así el Tribunal Constitucional apoyado en doctrina y jurisprudencia constitucional no doméstica, en su considerando cuadragésimo cuarto afirma: "Que, asi las cosas, esta Magistratura, por ahora, mantiene su criterio en cuanto a señalar que la determinación del órgano jurisdiccional que debe conocer, en el caso especifico de autos, de los contenciosos tributarios, es una materia que es privativa del legislador, por lo que no corresponde su revisión judicial por la vía de la jurisdicción constitucional, en tanto en cuanto en su 
aplicación no se acrediten infracciones sustanciales, concretas y precisas a la Carta Fundamental, lo que tampoco ha ocurrido en el caso de autos".

c) El Tribunal Constitucional utiliza el Derecho constitucional extranjero o la jurisprudencia de tribunales o cortes constitucionales extranjeras para constatar analogías o diferencias entre instituciones constitucionales o legales.

i) En sentencia rol $N^{\circ} 718$ de 26 de noviembre de 2007, el Tribunal Constitucional debió avocarse a razonar sobre el principio de reserva de ley en materia tributaria, para lo cual hará uso de la jurisprudencia constitucional extranjera norteamericano y europea para establecer similitudes con el Derecho constitucional chileno.

En este caso, Juan Díaz Cumsille, en representación de la Sociedad de Deportes Palestina S.A. formuló una acción de inaplicabilidad por inconstitucionalidad respecto de los artículos 1, 3, 4, 5, 7, 10, 12, y 16 de la ley $\mathrm{N}^{\circ}$ 20.033 , en la parte que ordena reemplazar el cuadro anexo $N^{\circ} 1$ de la ley $N^{\circ}$ 17.235, nómina de exenciones al impuesto territorial, párrafo I, exención del $100 \%$, letra b), № 3. La reclamación consiste en el reclamo de avalúo rol No 10.215-06, deducido ante el Tribunal Tributario Santiago Oriente, de acuerdo al artículo 149 del Código Tributario.

La requirente señala que, debido a que los preceptos legales impugnados que dicen relación con el establecimiento del impuesto territorial, particularmente en lo que se refiere a la forma en que se determinará la base imponible, haciendo referencia a la tasación y avalúo de los inmuebles y a la exención de dicho tributo, con intervención de la Administración, es necesario concluir que las normas impugnadas resultan decisivas en la resolución de la gestión pendiente.

El Tribunal Constitucional en el análisis del caso invoca la jurisprudencia del Tribunal Constitucional español en su considerando décimo octavo: “[...] Asi, por ejemplo, el Tribunal Constitucional español ha precisado que "si bien la reserva de ley en materia tributaria ha sido establecida por la Constitución (arts. 113 y 133 de la C.E.) de una maneraflexible, tal reserva cubre los criterios o principios con arreglo a los cuales se ha de regir la materia tributaria y concretamente la creación ex novo del tributo y la determinación de los elementos esenciales o configuraciones del mismo (STC 179/1985)".

Asimismo, el Tribunal Constitucional invoca la regulación constitucional del principio de legalidad tributaria en las constituciones norteamericana y europeas, en el considerando vigésimo: "Que en el Derecho comparado, como se ha indicado, el principio de legalidad tributaria ha sido ampliamente reconocido desde sus origenes en el mundo anglosajón. Así, la Constitución de Estados Unidos, en su articulo $1^{\circ}$, sección primera, establece que 'todo proyecto de leypara imponer tributos se presenta en la Cámara de Representantes', correspondiéndole 
al Congreso el imponer y recaudar contribuciones. En la Europa Continental también ha tenido amplio desarrollo. En Italia, por ejemplo, se establece que "no sepodrá imponer prestación personal o patrimonial sino en virtud de lo dispuesto en la ley" (articulo 23). Por su parte, el artículo 105 de la Carta Fundamental de Alemania otorga potestad legislativa exclusiva a la Federación en materia de aduanas y monopolios fiscales y concurrente sobre los demás impuestos. A su vez, la Constitución española indica que 'la potestad originaria para establecer tributos corresponde exclusivamente al Estado mediante ley' (artículo 113). La Constitución francesa también se encarga de entregar a la reserva legislativa lo referente a 'la base, tipo y modalidades de la recaudación de impuestos de toda clase' (artículo 34). En este último caso, ello se vincula -por lo demás- con la Declaración de derechos del hombre y del ciudadano, según la cual todos los ciudadanos tienen el Derecho de comprobar, por si mismos o por sus representantes, la necesidad de la contribución pública, de aprobarla libremente, de vigilar su empleo y de determinar su tipo, su base, su recaudación y su duración' (artículo 14). El principio de reserva legal también se ha extendido por nuestro continente iberoamericano. Así, como se señala ya en las conclusiones de la II Jornada Latinoamericana de Derecho Tributario, 'en virtud del principio de legalidad no podrápor vía de interpretación o de integración analógica, crearse obligaciones tributarias ni modificarse las existentes'. En armonía con ello, el Código Modelo para América Latina preceptúa que sólo por ley se puede 'crear, modificar o suprimir tributos, definir el hecho gravado de la relación tributaria, fijar la alicuota del tributo y la base de su cálculo e indicar el sujeto activo', además de "otorgar exenciones, reducciones o beneficios".

El Tribunal Constitucional también invoca la jurisprudencia de la Corte Suprema de México en el considerando vigésimo primero, en el análisis de la reserva legal en materia tributaria: "Que el principio de reserva legal tributaria, por lo demás, de acuerdo a sus origenes históricos, se encuentra fuertemente vinculado al principio de la soberania nacional. Por ello, la Corte Suprema de México precisa sobre el alcance del mismo que 'conforme con dicho principio, es necesario una ley formal para el establecimiento de los tributos, lo que satisface la exigencia de que sean los propios gobernados, a través de sus representantes, los que determinen las cargas fiscales que deben soportar, asi como que el contribuyente pueda conocer con suficiente precisión el alcance de sus obligaciones fiscales, de manera que no quede margen a la arbitrariedad' (Semanario Judicial de la Federación y Gaceta Judicial, Tomo VI, Noviembre, 1997, p. 78, cit. en Meza e Ibaceta, p. 208). [...]".

Análisis que continúa en el considerando vigésimo sexto, con referencias al Tribunal Constitucional español y a la Corte Suprema de México: "Que, sobre el punto, el Tribunal Constitucional español ha señalado que 'la reserva de ley se limita a la creación de los tributos y a su esencial configuración dentro 
de la cual puede genéricamente situarse el establecimiento de exenciones y bonificaciones tributarias' (STC 6/1983)./ A su turno, la Corte Suprema de México ha indicado que 'no se excluye la posibilidad de que las leyes contengan remisiones a normas reglamentarias, pero si que tales remisiones hagan posible una regulación independiente y no claramente subordinada a la ley, lo que supondria una degradación de la reserva formulada por la Constitución a favor del legislador".

El Tribunal Constitucional en su considerando trigésimo tercero explicitará el principio de reserva legal en materia tributaria en el texto constitucional, el cual es similar al existente en los ordenamientos constitucionales extranjeros examinados, como asimismo en las interpretaciones hechas por las jurisdicciones constitucionales extranjeras de sus respectivos ordenamientos constitucionales: "Que, en suma, si bien el principio de reserva legal no impide que se pueda entregar a la potestad reglamentaria de ejecución aspectos de detalle técnico de la obligación tributaria, es del caso reiterar que le corresponde al legislador señalar con precisión los parámetros, límites y ámbito de acción de la misma. En otras palabras, resulta contraria a la Constitución Política de la República la circunstancia de que la ley otorgue a la autoridad administrativa facultades discrecionales o genéricas para la regulación de los elementos esenciales de la obligación tributaria. De modo que si el tributo no se encuentra completamente determinado en la ley-por las características propias de toda obligación tributaria-, debe a lo menos ser determinable, sobre la base de los criterios claros y precisos fijados al efecto por el propio legislador, cumpliéndose asi el mandato constitucional en cuanto a que sólo le compete a aquél el establecimiento de tributos, como asimismo su modificación o supresión". Para, luego de analizar los textos legales impugnados, sostener en el considerando cuadragésimo que: "De todo lo dicho es posible concluir que, en principio, no vulnera la Constitución Política de la República el establecimiento del impuesto territorial, el que -como se ha expresado- encuentra sus fundamentos no sólo en las propias disposiciones constitucionales permanentes sino que también en las transitorias".

A su vez, en el considerando cuadragésimo quinto de la sentencia el Tribunal Constitucional determinará que el reproche que se formula de eventual desproporcionalidad del tributo, no es susceptible de apreciarse por falta de antecedentes que se hayan acreditado ante el tribunal: "[...] el reproche formulado por la requirente más bien parece una afirmación de carácter general y abstracto, y no se fundamenta especificamente en la situación concreta de autos, aunque podría eventualmente presentarse en consideración a la magnitud del tributo a pagar, todo lo cual ciertamente no se ha acreditado de manera circunstanciada y suficiente, lo que hace imposible que el requerimiento pueda prosperar en relación a este capitulo, a lo que debe agregarse que tratándose de 
recintos deportivos, y bajo ciertos y determinados supuestos previstos por la ley, seria procedente la exención del pago de las contribuciones, de todo lo cual se concluye que la aplicación eventual del impuesto territorial-establecido en el articulo $1^{\circ}$ de la Ley $N^{\circ} 17.235$ - al caso concreto de autos no presenta, por si misma, caracteristicas de abusiva, injusta o confiscatoria".

El Tribunal Constitucional examinando la constitucionalidad de la norma emanada de enunciados legales al caso concreto, señala que no hay inconstitucionalidad por tratarse de normas meramente procedimentales que fijan el procedimiento administrativo de reevalúo de bienes raíces, estableciendo parámetros, plazos y formas a los cuales debe sujetarse el Servicio de Impuestos Internos en el proceso de reevalúo y tasación de inmuebles que el legislador ha regulado en sus presupuestos fundamentales, de lo cual se puede reclamar a órganos jurisdiccionales: "Cuadragésimo noveno: Que, como puede apreciarse, esta disposición legal-particularmente el inciso primero que se reprocha - se limita a señalar que el Servicio de Impuestos Internos debe practicar, cada cinco años, un proceso - de carácter administrativo-de reavalúo de los bienes raíces agrícolas y no agrícolas. Del mismo modo, establece las fuentes a través de las cuales la entidad fiscalizadora puede obtener información acerca del valor de los inmuebles para los efectos de la nueva tasación, dentro de las que se incluye a los municipios y a los mismos propietarios. Finalmente, el precepto en cuestión da reglas y fija limites precisos a objeto de que del proceso administrativo de reavalúo que practique el Servicio de Impuestos Internos no se derive un aumento del tributo que resulte excesivamente gravoso para el contribuyente. Quincuagésimo: Que, de este modo, se trata más bien de una norma de carácter procedimental, que establece los parámetros, respecto de plazo y forma, a que debe sujetarse el Servicio de Impuestos Internos para los efectos del proceso de reavalúo y tasación de los inmuebles. Como puede apreciarse, el referido artículo $3^{\circ}$ se limita a fijar el ámbito o marco general de atribuciones dentro del cual debe actuar el Servicio de Impuestos Internos en el proceso de reavalúo y tasación de los bienes inmuebles, materia cuyos presupuestos fundamentales se encarga de precisar el propio legislador, habida consideración de que resulta imposible que este último pueda determinar por si mismo la valoración de las propiedades, materia que por sus caracteristicas técnicas y cambiantes debe necesariamente quedar entregada al órgano administrativo - el Servicio de Impuestos Internos-, existiendo en todo caso acción de reclamo o revisión ante órganos jurisdiccionales".

ii) En sentencia rol 759 de 26 de noviembre de 2007, el tema central del requerimiento es nuevamente la reserva de ley en materia tributaria

Con fecha 28 de marzo de 2007, Olga Matilde Hillmer Mundaca, en representación de la Sociedad Anónima de Deportes Manquehue, ha formulado una acción de inaplicabilidad por inconstitucionalidad respecto de 
los artículos 1, 3, 4, 5, 7, 10, 12 y 16 de la Ley $\mathrm{N}^{\circ} 17.235$ y del artículo 2 de la Ley $\mathrm{N}^{\circ} 20.033$, en la parte que ordena reemplazar el cuadro Anexo $\mathrm{N}^{\circ} 1$ de la Ley $\mathrm{N}^{\circ} 17.235$, nómina de exenciones al impuesto territorial, párrafo I, exención del $100 \%$, letra b), número 3 . Además, respecto del artículo 2 de la Ley $\mathrm{N}^{\circ} 17.235$, en la parte referida al cuadro anexo $\mathrm{N}^{\circ} 1$, nómina de exenciones al impuesto territorial, párrafo I, exención del 100\%, letra b), número 3.

En dicha sentencia, en el considerando décimo octavo, el Tribunal constitucional sostiene que "los elementos esenciales de la obligación tributaria deben quedarfijados suficientemente en la ley, no pudiendo efectuarse remisiones vagas y genéricas a la potestad reglamentaria de ejecución"

El Tribunal Constitucional en este caso, igualmente que en el caso anterior analizado, utilizará las mismas citas de Derecho constitucional extranjero señaladas en la sentencia anterior para demostrar la analogía existente entre el ordenamiento constitucional chileno con las disposiciones constitucionales de otros países sobre el principio de reserva legal en materia tributaria, como asimismo, la jurisprudencia coincidente existente en otras jurisdicciones constitucionales:

En el considerando vigésimo, el Tribunal Constitucional hace referencia nuevamente, como en el caso anterior analizado, rol No 718 , al Derecho constitucional comparado: "Que en el Derecho comparado, como se ha indicado, el principio de legalidad tributaria ha sido ampliamente reconocido desde sus origenes en el mundo anglosajón. Así, la Constitución de Estados Unidos, en su articulo 1, sección primera, establece que 'todo proyecto de ley para imponer tributos se presenta en la Cámara de Representantes', correspondiéndole al Congreso el imponer y recaudar contribuciones. En la Europa Continental también ha tenido amplio desarrollo. En Italia, por ejemplo, se establece que 'no se podrá imponer prestación personal o patrimonial sino en virtud de lo dispuesto en la ley' (artículo 23). Por su parte, el artículo 105 de la Carta Fundamental de Alemania otorga potestad legislativa exclusiva a la Federación en materia de aduanas y monopolios fiscales y concurrentes sobre los demás impuestos. A su vez, la Constitución española indica que 'la potestad originaria para establecer tributos corresponde exclusivamente al Estado mediante ley' (articulo 113). La Constitución francesa también se encarga de entregar a la reserva legislativa lo referente a 'la base, tipo y modalidades de la recaudación de impuestos de toda clase' (artículo 34). En este último caso, ello se vincula, por lo demás, con la Declaración de Derechos del Hombre y del Ciudadano, según la cual'todos los ciudadanos tienen el Derecho de comprobar, por si mismos o por sus representantes, la necesidad de la contribución pública, de aprobarla libremente, de vigilar su empleo y de determinar su tipo, su base, su recaudación y su duración' (artículo 14)". 
iii) La misma perspectiva de las dos sentencias analizadas, rol No 718 de 26 de noviembre de 2007 y rol No 759 de 26 de noviembre de 2007, se reitera en la sentencia del Tribunal Constitucional, con las mismas citas a la jurisprudencia constitucional extranjera y a las constituciones norteamericana y europeas, en la sentencia rol $\mathrm{N}^{\circ} 773$ de veintiséis de noviembre de 2007, en sus considerandos décimo octavo, vigésimo, vigésimo primero y vigésimo sexto.

\section{Conclusiones}

En el periodo analizado de 2006 y 2007 puede percibirse el paso de una práctica jurisprudencial del Tribunal Constitucional centrada sobre la Constitución formal como único elemento del parámetro de control de constitucionalidad a una apertura al Derecho internacional, lo que se explicita claramente en 2007 en una doble dirección, por una parte, el uso de los atributos de los derechos esenciales contenidos en el Derecho internacional de los derechos humanos en los tratados ("Hard Law"), la consideración de Resoluciones o directrices adoptadas por organismos internacionales ("Soft Law"); como, por otra parte, el uso del Derecho constitucional extranjero y la jurisprudencia emanada de jurisdicciones constitucionales de otros estados en un dialogo voluntario o espontáneo.

Es interesante anotar que el diálogo espontáneo con el Derecho constitucional extranjero y la jurisprudencia constitucional de otras jurisdicciones constitucionales es una práctica utilizada frecuentemente por el Tribunal Constitucional a partir de 2007 , lo que apenas se insinuaba en algunos votos concurrentes de sentencias en 2006.

Es un tema relevante para el análisis de algunas sentencias del Tribunal constitucional de 2006, mediante acciones de inaplicabilidad, en que el requirente funda su acción en disposiciones constitucionales y de Derecho internacional de derechos humanos, realizando el Tribunal el examen de constitucionalidad en base a los atributos de los derechos formalmente constitucionales y omitiendo toda consideración sobre las disposiciones de Derecho internacional de los derechos humanos que aseguran derechos esenciales invocadas y que como tales forman parte del parámetro de control de constitucionalidad de las disposiciones infraconstitucionales internas, lo que plantea la hipótesis de una sentencia no adecuadamente fundada en las fuentes del Derecho vigente, con la vulneración de las normas del Código de Procedimiento Civil sobre fundamentación de la sentencia y congruencia de la parte resolutiva de ella, como ocurre por ejemplo con el rol No 555.

En 2007 se inicia por parte del Tribunal Constitucional una práctica de integrar al parámetro de control de constitucionalidad derechos esenciales 
contenidos en el Derecho internacional de los derechos humanos ratificado por Chile y vigente, con el cual se enriquece el proceso jurídico a través del cual se considera la constitucionalidad o inconstitucionalidad de normas infraconstitucionales o se determina la aplicabilidad o inaplicabilidad por inconstitucionalidad en control concreto de preceptos legales.

La consideración de los derechos asegurados por tratados internacionales aparece en algunos casos como la manifestación de la sintonía entre la normativa interamericana y el texto constitucional, realizando la mención de las disposiciones de la Convención o Pacto internacional de derechos humanos; en otros, aparece como incorporación de los atributos del Derecho esencial regulado por el tratado integrado al contenido del Derecho constitucional que se utilizará como parámetro de control de constitucionalidad para enjuiciar a la norma infraconstitucional interna. Cercana a esta última perspectiva se sitúa la presentación en paralelo del canon constitucional y el canon normativo regional americano, apareciendo como parámetro conjunto para valorar la adecuación del acto impugnado al sistema constitucional de derechos humanos, conformando un bloque de criterios aplicables a una determinada situación, constituyendo una guía interpretativa.

Lo sorprendente y curioso del periodo analizado es que el Tribunal Constitucional nunca cita, pese a considerar como parte del parámetro de control de constitucionalidad los derechos contenidos en tratados internacionales ratificados y vigentes, los estándares mínimos sobre atributos y garantías de tales derechos fijados por las sentencias de la Corte Interamericana de Derechos Humanos, la cual constituye una jurisdicción vinculante y obligatoria, cuyas decisiones jurisdiccionales constituyen obligaciones de resultado para el Estado chileno y sus órganos, entre los cuales se cuenta el Tribunal Constitucional, siendo además la intérprete final del sentido y alcance de los derechos asegurados por la Corte Interamericana de Derechos Humanos, interpretación que vincula de buena fe al Tribunal Constitucional chileno. A su vez, no existe reflexión alguna en la jurisprudencia del Tribunal constitucional sobre la materia.

En tal sentido, el Tribunal Constitucional chileno no ha asimilado, como lo hace la generalidad de las Cortes Supremas y Tribunales Constitucionales de la región, la jurisprudencia de la Corte Interamericana sobre Derechos Humanos ni el control de convencionalidad que deben hacer los tribunales nacionales, como lo determinó la Corte Interamericana de Derechos $\mathrm{Hu}-$ manos precisamente en un caso chileno, "Almonacid Arellano y otros con Chile", sentencia dictada en 2006. Este control de convencionalidad es la base del desarrollo de un estándar mínimo de un ius commune interamericano, sin perjuicio del limitado margen de apreciación que tienen los tribunales nacionales en materia de derechos humanos. 
Esta perspectiva de no consideración de los estándares mínimos fijados por la jurisprudencia de la Corte Interamericana en materia de derechos esenciales por regla general no tiene explicación plausible, ya que el no respeto de tales estándares por parte del Tribunal Constitucional puede llevar a establecer la responsabilidad internacional del Estado por violación de derechos humanos. En este ámbito, el Tribunal Constitucional durante el periodo analizado no consideró en casos específicos los estándares mínimos fijados por la jurisprudencia de la Corte Interamericana en relación con la jurisdicción militar, la situación de tribunal independiente e imparcial, como asimismo, el juzgamiento por ella de civiles y la desorbitación de su competencia. Esta perspectiva, será más tarde corregida en su fallo sobre control preventivo obligatorio de modificaciones a la justicia militar $\left(\operatorname{rol~N} \mathrm{N}^{\circ} 1845\right)^{19}$.

Si bien no corresponde al periodo analizado en este trabajo, debe tenerse presente el caso “Aaron Vásquez”, el cual se encuentra ya en tramitación en el sistema interamericano, donde se omitió razonar bajo los estándares ya fijados por la Corte Interamericana en el caso "Herrrera Ulloa con Costa Rica”, como asimismo, en los estándares fijados por el Comité de Derechos Civiles y Políticos de Naciones Unidas acerca del Derecho a la revisión de la sentencia penal, que exigen que el recurso sea ordinario y que se revisen los hechos y el Derecho. Este puede ser el primer caso en que el Tribunal Constitucional puede verse agraviado por una sentencia condenatoria de la Corte Interamericana en virtud de un acto jurisdiccional propio.

El Tribunal Constitucional asume postulados de interpretación respecto del análisis de constitucionalidad de medidas legislativas que lesionan derechos fundamentales, o reglas de resolución de conflictos entre derechos fundamentales; en el periodo analizado, el Tribunal Constitucional utiliza el postulado o principio de proporcionalidad y sus subprincipios, el cual lo justifica en base a su recepción por la jurisprudencia de otras cortes constitucionales europeas (Alemania y España) o de cortes de la región americana (México), aún cuando no específica la intensidad de aplicación de éste.

En el análisis efectuado de las sentencias del Tribunal Constitucional en el periodo estudiado, este utiliza el Derecho constitucional extranjero y

${ }^{19}$ El fallo en considerando duodécimo determina: “Que esta Magistratura declarará que el artículo $1^{\circ}$ del proyecto de ley bajo examen no vulnera la Carta Fundamental, en el entendido de que en ningún caso los civiles y los menores de edad, cuando tengan la calidad de imputados, quedarán sometidos a la justicia militar;" y termina por declarar que: "1) Que el artículo $1^{\circ}$ permanente del proyecto de ley examinado es constitucional en el entendido que los civiles y los menores de edad en ningún caso podrán quedar sujetos a la competencia de los tribunales militares en calidad de imputados, quedando a salvo los derechos que les asisten para accionar ante dichos tribunales especiales en calidad de victimas o titulares de la acción penal". 
la jurisprudencia de tribunales o cortes extranjeras generalmente como reforzamiento de la argumentación desarrollada; para desarrollar clasificación de modelos de diversas instituciones jurídicas mediante la confrontación de ordenamientos jurídicos y para constatar analogías o diferencias entre instituciones constitucionales o legales.

En los casos analizados el Tribunal Constitucional en este periodo 20062007 no utiliza el Derecho constitucional y la jurisprudencia constitucional extranjera para considerar las soluciones dadas por el Derecho extranjero a temas que debe resolver el Tribunal; para aportar elementos que ayuden a generar la solución jurídica que se ajuste mejor al caso concreto; para constatar diferencias entre ordenamientos constitucionales; para alimentar el razonamiento jurídico que desarrollará el Tribunal Constitucional para resolver el caso o como elemento puramente decorativo o de erudición, perspectivas que podrían eventualmente considerarse en los años posteriores que continuaremos analizando en el curso de esta investigación.

Es necesario precisar que en general, en materia de utilización del Derecho no doméstico, específicamente, el Derecho constitucional extranjero, nuestro Tribunal Constitucional lo utiliza no en una perspectiva de Derecho comparado, ya que no hay un análisis de las instituciones en el contexto jurídico que ellas ocupan en dicho Derecho del respectivo Estado ni una consideración del sistema jurídico en que la institución opera, sino como mera información comparativa, muchas veces seleccionada discrecionalmente para obtener un respaldo para la posición preadoptada por el Tribunal o algunos de los ministros en sus votos concurrentes o disidentes. En tal sentido, parece necesario que el Tribunal Constitucional en sus fallos pueda evolucionar hacia una utilización más objetiva y justificada en el uso del Derecho no doméstico, como asimismo justificando el porqué utiliza una determinada normativa de un Estado y no de otro, como asimismo analizando el contexto de dicho uso, depurando la técnica y avanzando hacia un auténtico uso del Derecho comparado, el que siempre puede enriquecer la perspectiva y reflexión de nuestros jueces constitucionales.

\section{BIBLIOGRAFÍA}

Ackerman, Bruce, The Rise of Word Constitucionalism, en Virginia Law Review, 83 (1997).

BAzÁn, Víctor, El Derecho internacional de los derechos humanos desde la óptica de la Corte Suprema de Justicia de Argentina, en Revista de Estudios Constitucionales, 8 (Santiago, Centro de Estudios Constitucionales de Chile, Universidad de Talca, Ed. Abeledo Perrot - Legal Publishing, 2010) 2.

BURgorgue-LARSEn, Laurence, La formación de un Derecho constitucional europeo a través del diálogo judicial, en Asociación de Constitucionalistas españoles (editores), El Derecho constitucional europeo (Valencia, Tirant Lo Blanch, 2010). 
Canivet, G. The Practice of Comparative Law by the Supreme Courts: Brief Reflections on the Dialogue Between the Judges in French and European Experience, en Tulane Law Review, 80 (2006).

Carnota, Walter, Paper Uso del Derecho extranjero por Corte Suprema Argentina, en VIII Congreso Mundial de la Asociación Internacional de Derecho Constitucional, México, diciembre de 2010, "workshop" No 12: Enriquecimiento de la jurisprudencia a través del Derecho comparado, (México D. F., 2010).

CASTILla, Karlos, El Derecho de origen internacional en la interpretación constitucional de la Suprema Corte de Justicia de la Nación, en Revista Cuestiones Constitucionales, 23 (Ciudad de México, julio diciembre de 2010).

Corte Interamericana de Derechos Humanos, “caso López Álvarez vs. Honduras”, sentencia de $1^{\circ}$ de febrero de 2006 , serie C, No 141 , párrafo $170^{\circ}$.

Corte Interamericana de Derechos Humanos, caso "Almonacid Arellano y otros vs. Chile”, de 26 de septiembre de 2006, serie C, N 154.

Corte Interamericana de Derechos Humanos, caso "Palamara Iribarne vs. Chile", sentencia de 22 de noviembre de 2005 , serie $C, \mathrm{~N}^{\circ} 135$, párrafo $144^{\circ}$.

De Vergottini, Giuseppe, Oltre il dialogo tra le corti (Bologna, Il Mulino, 2010).

DrobNig , Ulrich - VAN ERP, Sjef (editores), The Use of Comparative Law by Court. Academia Internacional de Derecho Comparado (La Haya, Kluwer Law International, 1998).

Escobar-Martínez, Lina Marcela, El uso del precedente extranjero por parte de la Corte Constitucional colombiana, en Revista Colombiana de Derecho Internacional, 13 (Bogotá, noviembre de 2008).

HäBerle, Peter, Métodos y principios de la interpretación constitucional, en FERRER MAC-GREGor, Eduardo (coordinador), Interpretación constitucional (Ciudad de México, D.F., Porrua, 2005), I.

JACKSON, Vicky, Constitutional Engagement in a Transnational Era (Oxford - New York, Oxford University Press, 2010).

Lollini, Andrea, Confronting Comparative Methods: Approaches to Using Extra-Systemic Parameters by the Canadian Supreme Court and the South African Constitutional Court, en Muller, A. S. - Loth, M.A., Highest Courts and Internationalisation of Law (The Hague, Hague Academic Press, 2009).

Maus, Didier, Le recours aux précédents étrangers et le dialogue des cours constitutionnelles, en Revue Francaise de Droit Constitutionnel, 80 (2009).

Nogueira Alcalá, Humberto, El debido proceso en la Constitución y el sistema interamericano (Santiago, Librotecnia, 2007).

PONTHOREAU, Marie Claire, Le recours a l'argument de droit comparépar le juge constitutionnelle. Quelques problèmes théoriques et tecniques, en MÉLIN-SOUCRAMANIEN, Ferdinand (editor), L'interpretation constitutionnelle (Paris, Dalloz, 2005).

Queralt Jiménez, Argelia, Los usos del canon europeo en la jurisprudencia del Tribunal Constitucional: Una muestra del proceso de armonización europea en materia de derechos fundamentales, en Revista Teoria y Realidad Constitucional, 20 (2007).

Slaughter, Anne-Marie, A Global Community of Courts, 44 en Harvard International Law Journal, 44 (2003) 1.

SPERTI, Angioletta. Le difficoltà connesse al ricorso alla comparazione a fini interpretativi nella giurisprudenza costituzionale nel contesto dell'attuale dibattito sull'interpretazione, en Diritto Pubblico Comparato ed Europeo, 2 (2008). 